Review

\title{
Verdinexor Targeting of CRM1 is a Promising Therapeutic Approach against RSV and Influenza Viruses
}

\author{
Jennifer A. Pickens and Ralph A. Tripp * (1) \\ Department of Infectious Diseases, University of Georgia, Athens, GA 30602, USA; jenniferapickens@gmail.com \\ * Correspondence: ratripp@uga.edu; Tel.: +1-706-542-1557
}

Received: 9 December 2017; Accepted: 17 January 2018; Published: 21 January 2018

\begin{abstract}
Two primary causes of respiratory tract infections are respiratory syncytial virus (RSV) and influenza viruses, both of which remain major public health concerns. There are a limited number of antiviral drugs available for the treatment of RSV and influenza, each having limited effectiveness and each driving selective pressure for the emergence of drug-resistant viruses. Novel broad-spectrum antivirals are needed to circumvent problems with current disease intervention strategies, while improving the cytokine-induced immunopathology associated with RSV and influenza infections. In this review, we examine the use of Verdinexor (KPT-335, a novel orally bioavailable drug that functions as a selective inhibitor of nuclear export, SINE), as an antiviral with multifaceted therapeutic potential. KPT-335 works to (1) block CRM1 (i.e., Chromosome Region Maintenance 1; exportin 1 or XPO1) mediated export of viral proteins critical for RSV and influenza pathogenesis; and (2) repress nuclear factor $\mathrm{KB}(\mathrm{NF}-\mathrm{kB})$ activation, thus reducing cytokine production and eliminating virus-associated immunopathology. The repurposing of SINE compounds as antivirals shows promise not only against RSV and influenza virus but also against other viruses that exploit the nucleus as part of their viral life cycle.
\end{abstract}

Keywords: Chromosome Region Maintenance 1; Influenza; Respiratory syncytial virus; Verdinexor; KPT-335; antiviral

\section{Introduction}

Influenza A virus (IAV) and respiratory syncytial virus (RSV) are two leading causes of viral respiratory tract illnesses, resulting in considerable mortality and morbidity. The very young, elderly, and immunocompromised are at risk for developing disease associated with IAV or RSV infections. Both viruses share similar peak seasons that begin in the fall and proceed into early spring. According to the World Health Organization, the IAV and influenza B viruses (IBV) are responsible for seasonal epidemics causing approximately 3-5 million cases and upwards of 500,000 deaths worldwide [1]. The annual number of cases and hospitalizations vary depending on epidemic or pandemic years.

Current circulating influenza viruses consist of influenza A H1N1 and H3N2 strains, as well as influenza B Victoria-like and Yamagata-like strains [1]. The influenza virus is typically self-limiting, resulting in generally mild upper respiratory illness; however, in patients with underlying medical conditions, complications of infection can lead to severe disease and fatalities. Pneumonia, bronchitis, otitis media, and sinusitis are the common complications following IAV infections [2-4]. Like the influenza virus, RSV is an agent linked to viral respiratory illnesses, particularly in the very young and elderly [2,5-8]. RSV infections typically result in mild upper respiratory tract illness, but in severe cases, can cause bronchiolitis and pneumonia requiring hospitalization [8]. Annually, there are approximately 1 million pediatric cases in the US, where $70 \%$ of infants are infected by the first year of life and nearly every child by the age of $3[2,6]$. Prior exposure to RSV does not induce lifelong 
durable immunity; thus, the elderly ( $>65$ years of age) are at high-risk for serious and potentially life-threating complications associated with infection [5,9]. Each year there are nearly 10,000 deaths and over 177,000 hospitalizations reported for adults over the age of 65 in the US due to RSV [10].

Antiviral therapeutics generally target viral proteins needed for replication and many have proven to be ineffective at preventing influenza- and RSV-associated diseases due to features associated with the emergence of drug resistance. To avoid these issues, research efforts have focused on identifying and evaluating new antiviral drugs that target cellular factors and pathways hijacked by the virus used in replication, rather than focus on a viral component that may readily change under the selective pressure of the drug and/or immune system. The nuclear trafficking of viral components is a critical stage in the influenza virus and RSV replication. Inhibition of nuclear export not only attenuates viral replication but also impacts the regulation of immune-modulating factors [11-14]. In this review, we summarize the current understanding of targeting the host CRM1 (Chromosome Region Maintenance 1; exportin 1 or XPO1) dependent export pathway as a broad-spectrum antiviral therapeutic strategy against the influenza virus and RSV.

\section{Trafficking of Influenza and RSV}

\subsection{Influenza}

Influenza viruses are enveloped viruses of the Orthomyxoviridae family, comprised of a segmented, negative-sense single stranded RNA genome. The viral ribonucleoprotein (vRNP) complex consists of each viral RNA segment encapsulated by nucleoproteins (NP) and carrying its own heterodimeric RNA dependent RNA polymerase, comprised of polymerase basic 1 (PB1) polymerase basic 2 (PB2) and polymerase acidic (PA) subunits [15-18]. Each influenza subtype is defined by antigenically distinct hemagglutinin (HA) and neuraminidase (NA) glycoproteins (e.g., H1N1) with 18 HA and 11 NA subtypes identified in reservoir species such as shore birds, poultry and swine [19-21]. In humans, IAV infections are typically isolated to the upper respiratory tract. Upon infection, the HA facilitates viral entry by binding to $\alpha 2,6$ linked-sialic acids ( $N$-acetylneuraminic acid) of the surface of respiratory epithelium [22,23]. Proteolytic cleavage of the HA0 to the HA1 and HA2 subunits is required for viral infection. The M2 proton channel acidification of the endosome results in a conformational change in the HA, liberating the HA2 fusion peptide and thereby mediating fusion of the viral envelop with the host endosomal membrane and release of the vRNP complex into the cytoplasm [24-29]. The vRNPs are trafficked to the nucleus and subsequently imported by a group of proteins involved in transporting molecules between the cytoplasm and the nucleus of a eukaryotic cell called the karyopherin proteins that include importin- $\alpha[18,30,31]$. Although all of the protein subunits of the vRNP complex (NP, PA, PB1 and PB2) encode nuclear localization signals (NLS), it is the NP subunit that has been shown to be sufficient at modulating nuclear import of vRNPs, encoding 3 NLS motifs $[17,18,32,33]$. Once in the nuclear compartment, the viral RNA (vRNA) undergoes replication and transcription, generating progeny vRNPs that are then transported out of the nucleus and trafficked to the host membrane for assembly into progeny virions. IAV use the CRM1 nuclear export pathway to facilitate the nuclear to cytoplasmic transport of proteins bearing nuclear export signals (NES) [13,34]. Three viral proteins have been shown to be important for nuclear export. Although NP is the only protein of the vRNP complex to have a known NES, the viral M1 and nuclear export protein (NEP) have also been shown to be critical for vRNP complex nuclear export, where infected cells that lack M1 inhibit vRNP complex nuclear export (for review, see [13,34-36]).

\section{2. $R S V$}

Belonging to the Pneumoviridae family, RSV is an enveloped virus containing a non-segmented, negative-sense single stranded RNA genome [37]. The packaging of the RSV RNA into vRNPs is through encapsulation by nucleocapsid $(\mathrm{N})$ protein. The complex contains the viral RNA dependent RNA polymerase, compromised of the large polymerase (L) bound to its cofactors, the phosphoprotein 
(P) and the transcription elongation factor (M2-1) [38,39]. Within the virion, the vRNP is associated with the RSV matrix protein (M) by means of M2-1 protein. The RSV fusion (F) protein and attachment glycoprotein $(G)$ mediate viral entry in airway epithelial cells [40-44]. RSV gains entry through $G$ protein binding of glycosaminoglycans (GAG: heparin sulfate and chondrion sulfate GAG), followed by primary binding of RSV F to nucleolin and the embedding of cholesterol-rich micro domains at primary cilium and microvilli at the apical surface of respiratory epithelium [42,44-47]. Upon RSV F-mediated fusion of the viral envelop with the host plasma membrane, the vRNP dissociates from the M protein, delivering the viral genome to the cytoplasm allowing for RSV replication to occur. The replication process is not solely localized to the cytoplasm; although the RSV matrix (M) protein is trafficked to the nucleus early in the viral life cycle, at later time points it is found associated with vRNPs within replication centers called inclusion bodies [38,48,49]. The RSV M protein contains both NLS and NES motifs, shuttling into the nucleus via importin- $\alpha$ and out through CRM1 [12,50]. It is unclear what role the $\mathrm{M}$ protein plays within the nuclear compartment during early infection, but it may be linked to reductions in host transcription levels in RSV-infected cells [48]. The subcellular localization of RSV M protein within the nucleus is a critical step in the infection of cells, where CRM1 inhibition with the irreversible inhibitor leptomycin B (LMB) results in M protein nuclear accumulation and reduced RSV replication [12].

\section{Disease Interventions}

\subsection{Influenza Therapeutics and Vaccines}

To date, there are two classes of approved anti-influenza virus drugs available that target either the viral M2 or the NA proteins. Amantadine and rimantadine are IAV antivirals, and the mechanism of action of these drugs block the M2 proton channel shortly after viral entry, preventing delivery of the viral genome into the cytoplasm of the infected cell [51]. The M2 inhibitors are active against IAV strains, but not IBV. Widespread drug resistance is common among the amantadines. Resistance has been reported for the pandemic H1N1 (pH1N1) and H3N2 circulating viruses, and the CDC no longer recommends them as an IAV treatment option [52-54]. The NA inhibitors, oseltamivir and zanamivir, are the second generation of IAV antiviral drugs that mediate their effect by binding and blocking the enzymatic active site of the viral neuraminidase, thus causing the newly assembled virus to aggregate and preventing viral release and spread of infection to neighboring cells [55-61]. The NA inhibitors are effective against both IAV and IBV but must be administered within $48 \mathrm{~h}$ of infection [61-63]. While the rate of drug resistance to the NA inhibitors is not as widespread as with the M2 inhibitors, there have been reports of drug resistance [56,64]. Heightened concerns over the rising number of NA-resistant influenza strains has led to the use of oseltamivir and zanamivir though use is limited to complicated and high-risk IAV cases only [1,56,65]. Additional NA inhibitors have been developed that offer advantages over oseltamivir and zanamivir. Newly licensed Peramivir is now available in the US and utilizes an intravenous administration route, producing the same level of inhibition as compared to oseltamivir (oral) and zanamivir (inhalation) at lower dose concentrations [66-68]. Laninamivir, which is currently in phase III clinical trials, demonstrates long-acting inhibition when given as a single daily administration, whereas oseltamivir and zanamivir require twice daily dosing to be effective against influenza [69-74].

The influenza vaccine is considered by some as the best defense against influenza infections, but it requires annual administration to be prophylactically effective against seasonal circulating strains $[1,65]$. The viruses to be included in the influenza vaccine are predicted based on the previous season's circulating viruses. However, there are often issues with correctly matching the influenza viruses for a particular season, with mismatched seasons showing an increased number of influenza cases as compared to years where the vaccine is well matched to the circulating viruses $[65,75]$. Even when the vaccine is well-matched, it is still exhibits a range of effectiveness, varying from $10 \%$ to 
as high as $60 \%$ with the current 2017 vaccine only demonstrating $10 \%$ efficacy against the dominant H3N2 strain $[65,75]$.

Current research efforts are focused on development of a "universal" influenza vaccine and there are several in phase II clinical trials. Ideally, these would protect not only against the strains in circulation but also against emerging novel influenza strains. The premise of these vaccines is to target epitopes (e.g., HA stalk, M1, NP, and PB1 proteins) conserved among the various influenza subtypes and generate a potent neutralizing antibody response [65,75-80]. Preliminary data have shown evidence that a "universal" influenza vaccine is feasible, but it is still not clear how efficacious it will be against emerging strains and if it will demonstrate improved efficacy over the available seasonal vaccine $[65,76-79]$.

\subsection{RSV Therapeutics and Vaccines}

Unfortunately, there is no safe and effective RSV vaccine, despite $>50$ years of research effort. The choices to control RSV in infants and young children are limited to: (1) palivizumab, a humanized mouse monoclonal antibody against RSV $\mathrm{F}$ that is administered prophylactically in high-risk pediatric cases, and (2) ribavirin, a guanosine analogue that exerts an antiviral effect by inhibiting viral RNA synthesis and viral messenger (mRNA) capping [81,82]. The latter is only used to treat severe cases of RSV, despite limited evidence of efficacy and risk of toxicity $[81,83,84]$. As with other antivirals that target RSV, drug resistance is an issue with ribavirin, where drug resistant mutants limit its use [85-87]. Both therapeutics are costly and have only proven to be partially effective against RSV $[81,84,88-90]$. For uncomplicated cases, there are no therapeutic choices other than supportive therapy $[9,10]$.

Despite nearly 50 years of research efforts, no vaccine has been approved for RSV. While there has been progress in the development of a safe and efficacious RSV vaccine, the US Food and Drug Administration (FDA) is hesitant to approve an RSV vaccine, especially after the 1960 failure of the formalin-inactivated alum-precipitated RSV (FI-RSV) vaccine that resulted in enhanced disease, two deaths and hospitalization of $80 \%$ of the vaccinated subjects [91,92]. There are a number of candidates in clinical trials that have been reviewed in detail elsewhere $[93,94]$. Candidate vaccines currently used in clinical trials include live attenuated, subunit, vector and nanoparticle platforms in combination with a variety of different adjuvants. A large portion of the candidate vaccines focus on the RSV F protein, which is critical for viral entry, with the most advanced being the Novavax F-protein virus-like nanoparticle (VLP) vaccine adjuvanted with aluminum hydroxide, which is in phase III for maternal vaccination $[95,96]$. There is a need for a safe and effective vaccine for those at high risk for development of severe RSV disease (especially preterm infants), and there are only 3 candidate vaccines currently in phase I trials, both are recombinant live attenuated vaccines assessed in 6- to 24-month-old children [97]. These vaccines are attenuated by deletion of critical RSV genes (i.e., M2-2, SH, and NS2), while still eliciting a neutralizing antibody response [97]. Given the tragic history of the FI-RSV vaccine and the public concerns around vaccines, all vaccine candidates are extensively assessed for any counter indications with very few making it to the clinic.

Although ongoing research efforts to develop novel antivirals against RSV have led to several candidates, none have translated into new anti-RSV drugs (Table 1) [88]. Initially, antiviral drug research was aimed towards targeting RSV directly, but drug-induced selective pressures have resulted in mutant RSV that were less sensitive to the drug $[98,99]$. This illustrates the need for novel anti-RSV drugs that target host-mediated pathways essential for virus replication.

\subsection{Potential Directions to Discover Novel Therapeutics against RSV and Influenza}

Even with the available therapeutics targeting RSV and IAV, these viruses still remain a persistent public health and economic burden. Work is underway to identify novel and efficacious drug alternatives that target every aspect of the viral pathogenesis in the host, as well as block the immune modulating factors shown to cause immunopathology. This approach will lead to the development of novel immunomodulatory drugs, antiviral agents, and vaccines, while also assessing natural products 
in the treatment of RSV and IAV. Nearly every step within the virus life cycle from viral entry to egress can be targeted, either by interfering with the function of a viral protein itself or through inhibition of the host pathway hijacked by the virus. A brief overview of anti-RSV, anti-IAV and immunomodulatory therapeutics currently under investigation has been provided (Table 1) and recently reviewed elsewhere [93,94,100,101].

Table 1. Therapeutics under investigation against respiratory syncytial virus and influenza viruses.

\begin{tabular}{ccc}
\hline Drug Name & Target & Reference(s) \\
\hline GS-5806 & RSV inhibitors & \\
NMSO3 & RSV F protein & {$[102-104]$} \\
RSV 604 (benzodiazepine) & RSV G protein & {$[105,106]$} \\
VP-14637 & RSV N protein & {$[107,108]$} \\
AZ-27 & RSV F Protein & {$[109-111]$} \\
ALS-008176 & RSV L protein & {$[112]$} \\
Nitazoxanide & RSV L protein & {$[113,114]$} \\
& Pyruvate: ferredoxin oxidoreductase (PFOR) enzyme & {$[115]$} \\
& dependent electron transfer reaction & \\
\hline Nitazoxanide & IAV inhibitors & {$[115,116]$} \\
Favipiravir & HA protein & {$[117,118]$} \\
VX-787 & RNA dependent RNA polymerase complex & {$[119-121]$} \\
AL-794 & PB2 protein & {$[122]$} \\
Nucleozin & PA protein & {$[123,124]$} \\
DAS181 & NP protein & {$[125-127]$} \\
\hline & Fusion inhibitor & {$[128,129]$} \\
\hline Eritoran (E5564) & TLR4 antagonist & {$[130]$} \\
Rosiglitazone/pioglitazone & Peroxisome proliferator-activated receptor $\gamma$ antagonist & {$[131]$} \\
Azithromycin (macrolides) & Interferon-augmenting & \\
\hline
\end{tabular}

Abbreviations: F: Fusion; G: Attachment; N: Nucleoprotein; L: Large Polymerase; HA: Hemagglutinin; PB2; RNA polymerase Basic 2; PA: Polymerase Acidic; NP: Nucleoprotein; TLR4: Toll-like Receptor 4.

\section{Influenza and RSV-Induced Inflammatory Response}

Influenza and RSV are pathogens that predominately infect the respiratory epithelium and must overcome intrinsic barriers to establish infections. Uncomplicated cases of infection by these viruses result in upper respiratory tract illnesses with mild symptoms including sinusitis, cough, sore throat, headache, fever, anorexia and myalgia [1,4,132]. In more complicated cases, the patient may present with severe bronchiolitis, pneumonia, pulmonary function abnormalities, apnea and secondary bacterial infections $[1,4,133]$. All of these symptoms are linked to a virus-induced inflammatory response. This response is a key defense process designed to protect the host against invading pathogens; however, an uncontrolled and heightened response may be associated with intense tissue damage with the most extreme cases resulting in fatalities [133-136]. In enhanced IAV disease, pro-inflammatory cytokines and chemokines can cause damage to pulmonary tissues, leading to respiratory dysfunction or acute respiratory distress syndrome (ARDS) $[3,133,135,136]$. RSV infection has been associated with acute and chronic complications that include recurrent wheezing, allergic airway disease and pulmonary function abnormalities [137-142]. Disease severity is greatly associated with an exacerbated innate immune response, where high levels of cytokines and chemokines cause localized tissue pathology and a cytopathic effect.

In this review, we discuss influenza- and RSV-induced immune factors that contribute to inflammation, and the recruitment of various leukocyte populations to the lung parenchyma and airway space. The recruitment of immune cells to the sites of infection is dependent on virus sensing and the release of inflammatory mediators. Influenza virus and RSV are both single-stranded RNA viruses that modulate the host innate immune response through similar pathways. Once these viruses gain access to the respiratory tract, the innate immune response is initiated by the pattern recognition 
receptors (PRR) of the lung microenvironment that are capable of recognizing pathogen-associated molecular patterns (PAMPS) of the invading virus [143]. RSV and influenza virus infections can activate PRRs that include Toll-like receptors (TLR), retinoic acid-induced gene I like receptor (RIG-I; RLR) and nucleotide-binding domain (NOD)-like receptors (NLR) (Figure 1) [132,143-146]. PAMP interaction with PRRs induces innate cytokines and chemokines that drive and promote inflammation and the recruitment of immune cells to the sites of infection in the upper airway and lungs. These PRRs are able to recognize multiple forms of RNA and respond by initiating intracellular signaling pathways and nuclear trafficking of transcription factors involving nuclear factor- $\mathrm{kB}(\mathrm{NF}-\mathrm{kB})$, interferon regulatory factors (IRFs) and activating transcription factor 2 (ATF-2)/c-Jun [143,144,147].

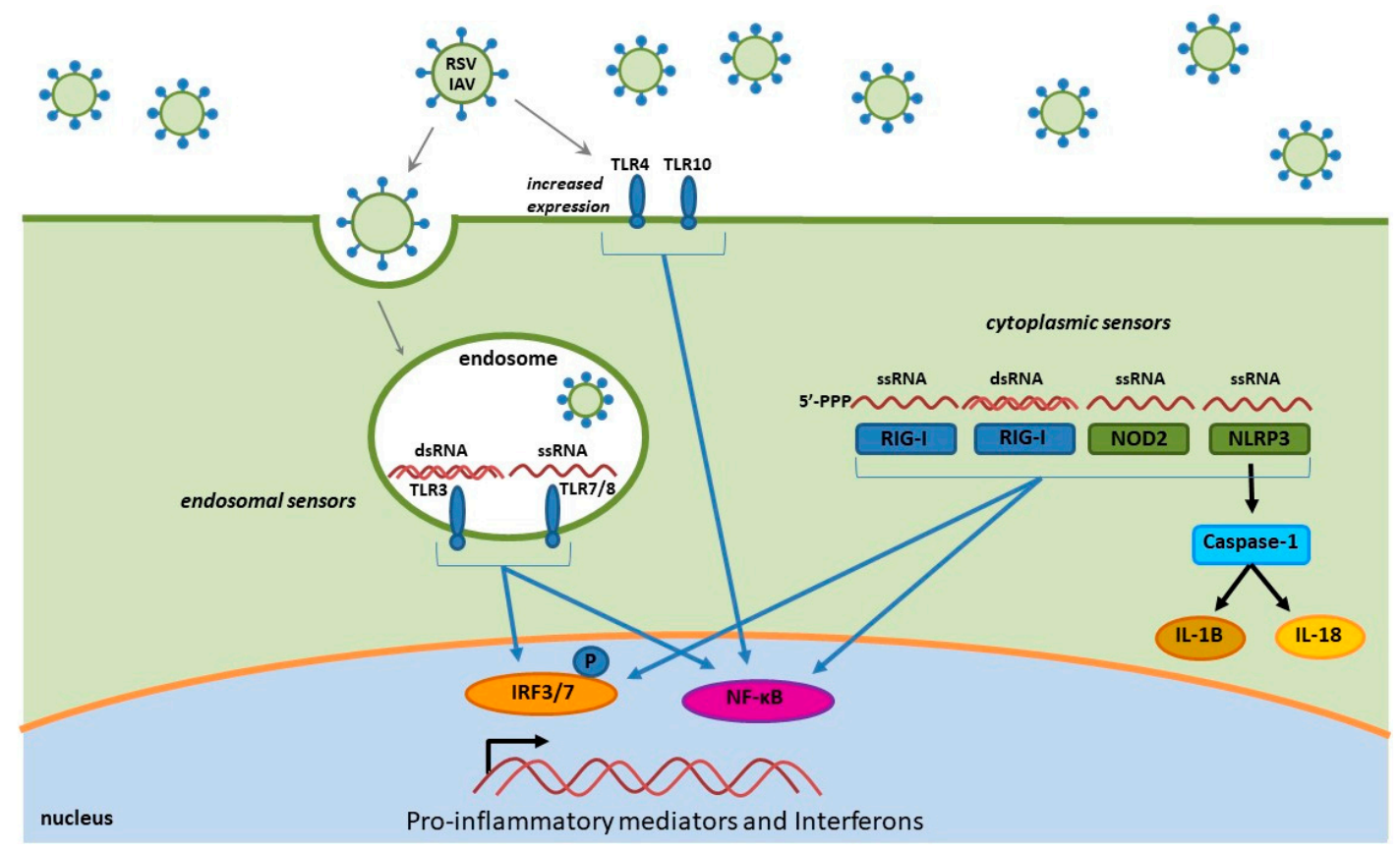

Figure 1. RSV and IAV single-stranded RNA and double-stranded RNA moieties generated during viral replication are detected by both endosomal Toll-like receptors (TLR) 3 and TLR7/8, and cytoplasmic pattern recognition receptors (PRRs), resulting in activation of transcription factors interferon regulatory factors (IRF) 3, IRF7, and nuclear factor $\mathrm{\kappa B}$ (NF- $\mathrm{kB}$ ) production of pro-inflammatory cytokines, chemokines, and interferons. RSV and IAV have also been shown to increase expression of cell surface TLR4 and TLR10 PRRs that lead to NF- $\mathrm{kB}$ induced transcription of pro-inflammatory cytokine genes. Both viruses are detected by NLRP3 NLRs and activate the inflammasome pathway and downstream expression of IRF3 and NF- $\mathrm{KB}$ dependent immune responses, as well as direct production of interleukin (IL)-1B and IL-18.

\subsection{Toll-Like Receptors}

Toll-like receptors are distributed into two general groups: (1) those that recognize proteins and expressed on the plasma membrane (TLR1, TLR2, TLR4, TLR5 and TLR6) including lipopolysaccharides (LPS), flagellin and other proteins, and (2) those that recognize nucleic acids presented intracellularly within the endosomal compartment (TLR3, TLR7, TLR8 and TLR9) [148-150]. TLRs are expressed on many immune cells types including dendritic cells, macrophages, B and T cells, and neutrophils, as well as non-immune cells, such as fibroblast cells, epithelial cells, and keratinocytes [148,151]. Virus detection by TLRs activates downstream transcription factors that regulate cytokine and chemokine expression, including NF-kB, IRFs and ATF-2/cJun [143,144,147]. For the influenza virus and RSV, the TLR3 and TLR7/8 responses are involved in the detection of dsRNA and ssRNA, respectively [148]. The TLR3 is the most abundant and constitutively expressed 
receptor in human respiratory epithelial cells [152]. During infection, the TLR3 and TLR7/8 PRRs detect viral nucleic acids generated during IAV and RSV replication, triggering the production of pro-inflammatory cytokines and chemokines and inducing an antiviral response, while also negatively contributing to the pulmonary immunopathology. Other TLRs (TLR4 and TLR10) have been shown to have a role in the innate immune responses to IAV and RSV infections with an increase in TLR expression upon infection, ultimately resulting in an increase of pro-inflammatory cytokine production that sensitizes lung epithelium to other PAMPs (i.e., LPS and endotoxin) [153-155].

\subsection{RIG-I-Like Receptors}

Retinoic acid-induced gene I like receptor (RIG-I) and MDA5 are cytoplasmic PRRs critical for sensing both viral dsRNA and ssRNA in most cells, including alveolar macrophages, conventional dendritic cells, and lung epithelial cells [156]. The RLRs are activated by viral nucleic acid containing a $5^{\prime}$ triphosphate moiety and forming secondary "panhandle" double stranded RNA structures, which aide in the ability of the RIG-I to distinguish viral RNA from self $[157,158]$. Detection of either RSV or IAV viral RNA by the RLR cytoplasmic sensors results in recruitment and activation of the mitochondrial antiviral signaling protein (MAVS), leading to induction of the NF- $\mathrm{KB}$ and IRF3 pathways and production of pro-inflammatory cytokines and type I and II interferons (IFNs) [158,159].

\subsection{NOD-Like Receptors}

The multi-protein inflammasome complexes, comprised of NLRs, the adapter (apoptosis-associated speck-like) ASC protein and pro-caspase- 1 are activated upon cleavage of pro-caspase- 1 into its active form $[160,161]$. Once in the active form, the complex proceeds to cleave the pro-IL-1 $\beta$ and pro-IL-18 into IL-1 $\beta$ and IL-18, which in turn mediate the inflammatory response to RSV and IAV [161-164]. The NLR pyrin domain containing 3 (NLRP3) is the most characterized NLR in the context of virus infections, where activation results in initiation of the inflammasome pathway and downstream activation of the NF-KB and IRF3 induced pro-inflammatory response. NLRP3 is expressed by a variety of myeloid cells that include monocytes, dendritic cells, neutrophils macrophages and respiratory epithelial cells [161]. NLRP3 is able to sense both RSV and IAV infections resulting in increased NLRP3 expression in the lungs, as well as immune cells recruited to the site of infection [161,165]. Viral proteins are able to induce the inflammasome cascade (the short hydrophobic (SH) protein of RSV, as well as the M2 and PB1-F2 of influenza) and while activation of the NLRP3 is important for virus clearance, a consequence of activation is an exacerbated inflammatory response in severe cases of IAV [161,164-166]. Another NLR shown to be influenced by RSV and IAV is NOD2, where both viruses result in increased NOD2 expression and subsequent activation of both IRF3 and NF- $\mathrm{kB}[167,168]$.

\subsection{RSV and Influenza Induced Immune Mediators}

Interferons, cytokines, chemokines are mediators of the inflammatory immune response of the respiratory tract [143]. These hormones facilitate immune and non-immune cell communication and drive leukocyte trafficking, epithelium activation, cellular proliferation and differentiation, and initiation of the adaptive immune response $[143,169]$. Not only do cytokines activate, regulate and control the immune response, they can establish an antiviral state, and facilitate clearance of virus, and they have been shown to promote destructive immunopathology during infection $[143,170]$.

A role of PRRs is to initiate the activation and nuclear translocation of two transcription factors, IRF3 and NF- $\mathrm{KB}$, that induce the production of pro-inflammatory cytokines and chemokines that coordinate the inflammation response and the recruitment of immune cells to the sites of infections. These immune cells include neutrophils, eosinophils, macrophages, monocytes, dendritic cells, memory $\mathrm{T}$ cells, Th1 cells and natural killer (NK) cells $[146,162]$. The influx of recruited immune cells then stimulate the secretion of a second round of cytokines, which ultimately can cause increased pathology associated with inflammation. NF- $\mathrm{kB}$ activation by IAV and RSV induces the expression of peculiar pro-inflammatory cytokines and chemokines. For example, RSV infection initiates the production of 
IFN $\alpha$, IFN $\beta$, monocyte chemoattractant protein 1(MCP1), IP10/CXCL 10, RANTES/CCL ${ }_{5}$, IL6 and IL8/CXCL 8 , while IAV triggers secretion of IFN $\alpha$, IFN $\beta$, IFN $\gamma$, RANTES/CCL $L_{5}$, IL8/CXCL 8 , IL6, IL-12p40/p70 and granulocyte colony-stimulating factor (G-CSF)[171-175]. An exacerbated increase of pro-inflammatory cytokines and influx of immune cells to infected tissues is directly linked to disease severity and poor prognosis $[135,176,177]$. A portion of RSV-infected children that develop severe disease, such as bronchiolitis and pneumonia, have been linked to recurrent childhood wheezing and higher rates of asthma than children that had uncomplicated RSV infections, especially within the first 6 months of life [137,138,142,178]. Like RSV, IAV may cause ARDS [134,136]. Patients that develop ARDS and died from IAV were shown to have hypercytokinemia and massive pulmonary pathology, where histopathology consisted of inflammation, necrosis of the large airway epithelium, alveolar edema, hemorrhage and diffuse alveolar damage $[136,179]$. Several studies have examined cytokine profiles from patients that developed fatal ARDS as compared to those that presented mild disease. Collectively, the cytokines elevated in severe cases of 2009 H1N1 infection have been shown to have exacerbated increases of most pro-inflammatory cytokines included G-CSF, tumor necrosis factor (TNF $\alpha$ ), IFN $\alpha 2$, IL-1 $\alpha$, IL-1b, IL-2, IL-6, IL-8,IL-9, IL-10, IL-12, IL-15, IL-17, IL-23, IP-10, MCP1 and macrophage inflammatory protein $1 \beta$ (MIP1 $\beta)[133,134,180,181]$.

\section{Immune Evasion}

Viruses employ countermeasures to attenuate the host response to infection and replication. Classically, nonstructural (NS) proteins have been shown to mediate a role in immune evasion, and facilitate their effects through interactions with cellular factors known to regulate the immune response to infections [182]. The influenza virus NS1 protein inhibits RIG-I/interferon-beta promoter stimulator 1(IPS-1) complexes and blocks type I IFN expression and pro-inflammatory cytokine expression [183-185]. NS1 proteins expressed by some influenza virus strains have been shown to inhibit the maturation of cellular mRNA and subsequent nuclear export by binding and blocking the host's cellular cleavage and polyadenylation specificity factor (CPSF), thereby potentially attenuating cytokine production and export by infected cells [186].

It is important to note that RSV encodes not only NS proteins but also additional proteins to modulate the host's immune response. The nonstructural proteins 1 and 2 (NS1 and NS2) work antagonistically to inhibit the IRF3 mediated transcription of type I and II IFNs, i.e., IFN $\alpha$, IFN $\beta$ and IFN $\gamma$, in RSV-infected epithelial cells [187]. The NS proteins induce increased levels of suppressors of cytokine signaling (SOCS) proteins-1 and -3, which work through a negative feedback loop involving the Janus kinase-Signal Transducer and Activator of Transcription (JAK-STAT) pathway to regulate the activation and expression of IFN genes [188,189]. The RSV G protein also exhibits several immunomodulatory features that help control the immune response to infection, such as cytokine mimicry, inhibition of TLR activation pathways, and secretion of soluble forms to bind and disable neutralizing antibodies [190-193]. Interestingly, the RSV G protein contains a CX3C (fractalkine) chemokine motif capable of binding to the fractalkine CX3CR1 receptor to modify leukocyte trafficking and block RSV-mediated pathogenesis $[191,194,195]$. In addition, the RSV G protein is also able to attenuate type I IFN and interferon-stimulating gene (ISG)-15 expression through SOCS-1 and -3 induction, through interference of TLR signaling [190].

\section{Therapeutic Potential of Targeting CRM1}

Despite substantial research efforts to develop and implement antiviral measures against RSV and influenza virus, there has only been modest progress. While annual influenza vaccines are available, antigenic variations and poor strain matching ultimately reduce the efficacy of the vaccine [65]. For RSV, there is no available vaccine, and a handful of vaccine candidates are being clinically tested. Both viruses have US FDA approved antiviral drugs as discussed earlier, but these have limited effectiveness, requiring administration shortly following infection to have therapeutic value. In addition, overuse of antivirals has put selective pressure on the virus to develop mutations, driving 
the outgrowth of resistant strains. There is a significant need for novel antivirals and the focus of current research has shifted from the virus to targets within cellular pathways exploited by the virus for replication. The challenge is to develop an antiviral drug that is well-tolerated with minimal cytotoxicity and effective against a wide range of viruses. In this review, we explore the anti-influenza virus and anti-RSV capability of selective inhibitors of nuclear export (SINE) that specifically targets the CRM1 nuclear-cytoplasmic export pathway. Since RSV and the influenza viruses utilize the nucleus during part of their viral lifecycle, targeting the nuclear export machinery is a good antiviral approach that could act not only by inhibiting viral replication but also by attenuating the immune response by interfering with the regulation of transcription factors and production of pro-inflammatory cytokines and chemokines. There are several reviews covering CRM1 structure, function and applications targeting CRM1 as a cancer chemotherapeutic [196-199]. This review will provide an overview of CRM1 and the rationale for targeting nuclear export as a feasible antiviral strategy against influenza and RSV infections.

\subsection{CRM1 and Nuclear Export}

Nuclear import and export of all large proteins $(>40 \mathrm{kDa})$ are mediated by transporter molecules and members of the karyopherin- $\beta$ family of proteins. There are currently19 members of the karyopherin- $\beta$ family, where each molecule is responsible for the transport of cargo proteins and RNA [196,200]. Nucleocytoplasmic transport occurs via the highly selective nuclear pore complex (NPC). The NPC is one of the largest multimeric protein complexes in the cell at $125 \mathrm{MDa}$, comprised of nearly 100 different nucleoporins [201-203]. While there are seven identified karyopherin- $\beta$ export proteins, CRM1 is the best characterized of the nuclear export proteins and is conserved among fungi, yeast, mice, and humans [196,204]. It is a ubiquitous nuclear transporter protein that mediates the nuclear to cytoplasmic export of over 240 large proteins and RNA moieties that encode hydrophobic NES motifs [201,202,205-209]. Hydrophobic NES-bearing cargos bind within the Cys528 active site of the hydrophobic NES binding grove located on the outer convex surface of CRM1, which adopts three possible confirmations based on its ability to bind NES-bearing cargo and RAs-related nuclear guanosine triphosphate (RanGTP): (1) inactive with a closed NES groove unable to bind cargo; (2) active with open NES grove bound to RanGTP and cargo; and (3) intermediate with cargo bound in the absence of RanGTP [198]. Export is initiated in the nucleus where it binds the cargo and RanGTP to form a trimer that actively transports the cargo across the NPC via facilitated diffusion. Once the complex is transported to the cytoplasm, the RanGTP is hydrolyzed into RanGDP, resulting in the dissociation of the trimer and release of the cargo into the cytoplasm [208-210]. The CRM1 and RanGDP are then recycled back to the nucleus where they can undergo another round of export. The energy required to facilitate the CRM1 export process is generated by a high RanGTP concentration gradient in the nucleus, driving the facilitated nuclear export of cargo proteins to the cytoplasm [210].

\subsection{SINE Inhibition of Influenza and RSV}

Selective inhibitors of nuclear export (SINE) compounds are designed to bind exportin receptors and inhibit the cytoplasmic transport of NES-bearing cargo proteins. Preliminary studies have focused on the use of SINE compounds as anti-cancer therapeutics, since the inhibition of CRM1-mediated export results in nuclear retention of tumor suppressing proteins (TSP) and cell cycle regulators (CCR), allowing them to impose cell cycle control and selective apoptosis in several tumor types including ovarian, pancreatic cervical, mammary, and lymphoma cancer cells [211-214]. In recent studies, SINE compounds have shown antiviral activity against viruses that utilize the nucleus as part of their viral life cycle. While LMB is the prototypical inhibitor used to characterize CMR1 trafficking, its irreversible binding, and off-target effects cause it to be highly toxic and not a suitable antiviral candidate $[215,216]$. Karyopharm Therapeutics has recently developed first-in-class, novel selective inhibitors of nuclear export (KPT-SINE) using molecular modeling to screen and identify compounds that interact with the NES groove of CRM1 $[208,209,217]$. KPT-SINE compounds are reversible 
inhibitors of CRM1-mediated nuclear export, and the crystal structure revealed that a SINE molecule binds within the NES binding pocket of CRM1 and appears to penetrate deeper into the groove than LMB [217]. One of the KPT-SINE compounds, Verdinexor (KPT-335), is an orally bioavailable well-tolerated compound that has exhibited efficacy as an anti-cancer and antiviral drug. In initial preclinical work, KPT-335 was shown to effective cancer chemotherapy against canine lymphomas, but our group has also demonstrated the potential of KPT-335 as a novel broad-spectrum antiviral against various IAV and IBV strains and RSV (unpublished) [14,211,213,218,219].

We examined the potential of KPT-335 as a broad-spectrum antiviral against various influenza strains in vitro and in vivo [14,218]. KPT-335 was shown to be efficacious at reducing virus replication of pandemic H1N1 (A/California/04/09), highly pathogenic H5N1 avian influenza strain and the recently emerged H7N9 in vitro [14]. Furthermore, KPT-335 treatment was also shown to reduce virus burden, lung pathology and cytokine expression in mice and ferrets against pandemic H1N1 (A/California/04/09) and H3N2 (A/Philippines/2/82) [218]. We assessed the expression of key NF- $\mathrm{KB}$ dependent cytokines and demonstrated substantial reduction in the expression of $\operatorname{IFN} \gamma(p \leq 0.05)$, $\mathrm{TNF} \alpha(p \leq 0.01)$, IL-1 $\beta(p \leq 0.01)$, and IL-6 $(p \leq 0.05)$. In our most recent report, KPT-335 treated mice had considerably lower IFN $\gamma$ and TNF $\alpha(p \leq 0.05)$ in bronchoalveolar lavage fluid (BALF) and reduced levels of IL-6 and IL-12p40 at day 2 through day 4 pi. In addition, there was no substantial increase in inflammatory cell infiltrates (macrophages, natural killer cells, $\mathrm{T}$ cells and granulocytes) detected in the mice. While in ferrets, lower numbers of infiltrating leukocytes were observed in all KPT-335 treated ferrets as early as day 2 post-infection (pi) and turned to significant reductions by day 4 post infection. Ferrets that received KPT- 335 up to $25 \mathrm{mg} / \mathrm{kg}$ once daily or $10 \mathrm{mg} / \mathrm{kg}$ twice daily showed reduced expression of IL-12p40 ( $p \leq 0.01)$, IFN $\gamma$ and TNF $\alpha(p \leq 0.01)$ in nasal exudates as early as day 2 pi. We demonstrated that KPT-335 mediates its effect by disrupting CRM1-NEP binding, resulting in potent and selective nuclear retention of the vRNPs and thereby blocking their ability facilitate viral replication and assembly processes (Figure 2).

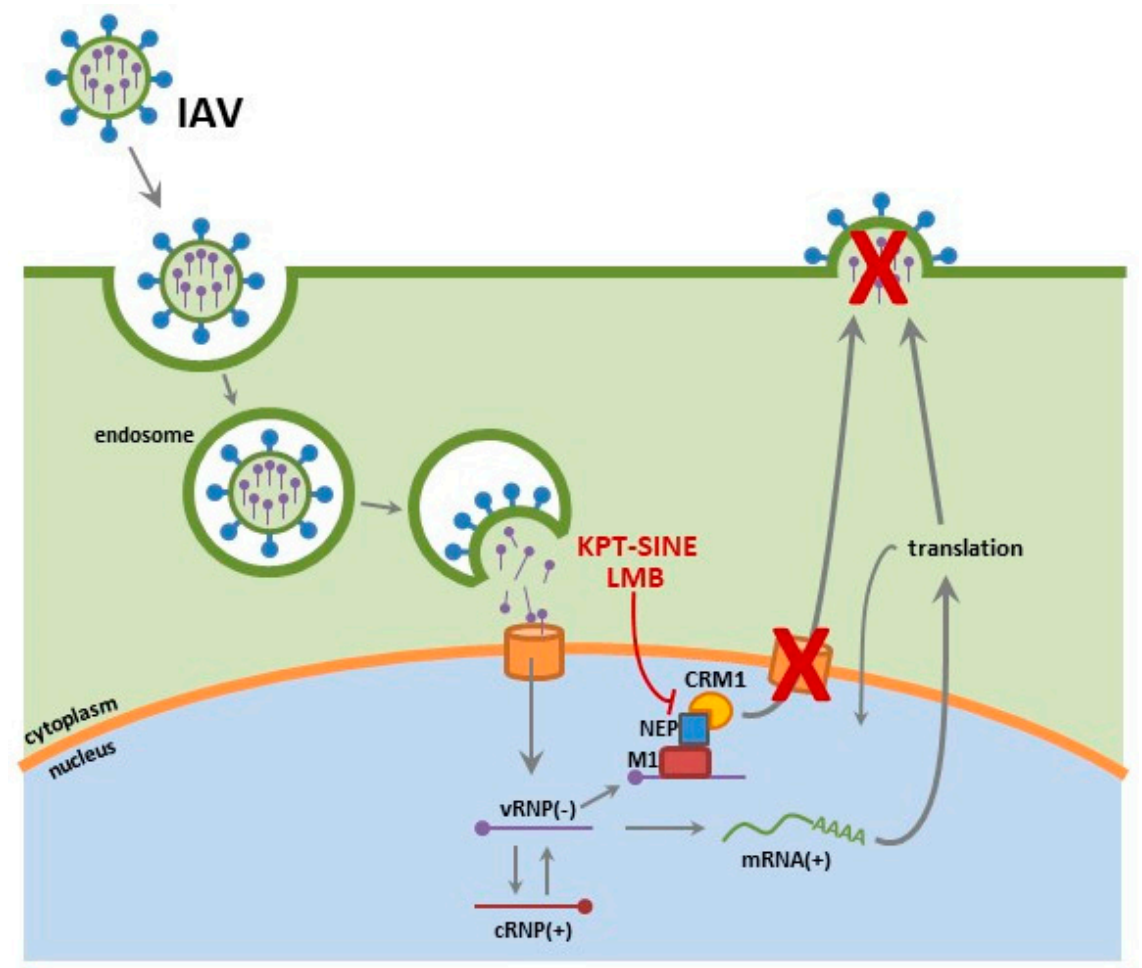

Figure 2. Select inhibitors of nuclear export (SINE) interfere with CRM1 mediated export of the IAV viral ribonucleoproteins (vRNPs), thereby sequestering them to the nucleus and inhibiting late stage assembly processes. 
We have preliminary data demonstrating KPT-335 as a safe and effective anti-RSV therapeutic. In these studies, therapeutic administration (2 hours pi) of KPT-335 reduces replication of RSV A2, RSV Long and RSV B1 strains. Slight RSV M nuclear accumulation was detected in KPT-335-treated respiratory epithelial cells; thus, we hypothesize that the observed virus reduction was due to nuclear sequestering of the RSV M protein, where it is unable to facilitate viral assembly and budding processes essential for virus replication (Figure 3). In addition, the expression of IL-8, RANTES, and growth regulated protein alpha $(\mathrm{GRO} \alpha)$ and MCP-1 was reduced in KPT-335 treated A549 cells (i.e., respiratory epithelial cells) as compared to the mock-treated controls, although not statistically significant. We are currently investigating the in vivo efficacy of KPT-335 against RSV in an RSV-experienced mouse model. We propose that KPT-335 treatment will reduce viral burden, lung pathology and cytokine expression similar to what was observed in the influenza virus studies. We hope to demonstrate the broad-spectrum antiviral activity of KPT-335 against RSV A and B strains in a RSV-experienced mouse model. These results will complement previous studies showing KPT-335 efficacy against strains of IAV. Additionally, we seek to better understand the interactions of the RSV M protein with host cellular factors and determine their influence on cellular processes.

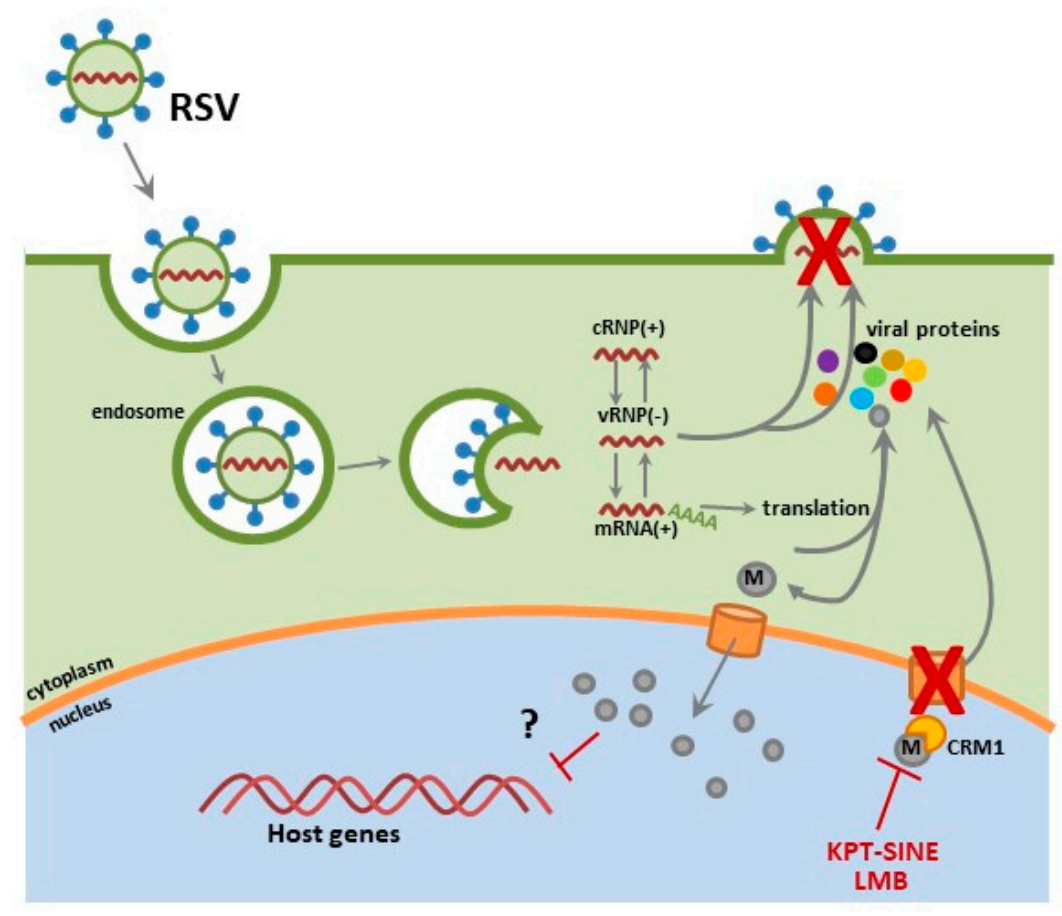

Figure 3. Respiratory syncytial virus (RSV) matrix (M) protein translocates to the nucleus early in the infection life cycle and inhibition of CRM1 export by leptomycin (LMB) or KPT-SINE reduces viral production and results in $\mathrm{M}$ protein nuclear accumulation.

\subsection{CRM1 Inhibition of $N F-\kappa B$}

Inhibition of nuclear export works not only to block export of viral proteins but also interferes with downstream immunomodulatory responses triggered by early stages of the viral infection cycle. It is the recognition of viral PAMPs present at each stage of pathogenesis (i.e., entry, fusion, transcription, translation and assembly) that drives activation of cellular and downstream immune responses. SINE compounds work to block nuclear to cytoplasmic export of viral and immune mediators that utilize CRM1 as part of their regulator pathways, resulting in attenuated functionality.

Select inhibitors of nuclear export (SINE) compounds, while effective as a possible antiviral drugs and chemotherapeutics, have exhibited anti-inflammatory activities by disrupting NF- $\mathrm{B}$ regulation

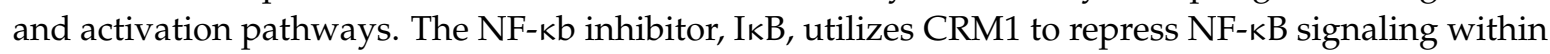


both the nuclear compartment and the cytoplasm $[220,221]$. The I $\kappa$ B bound to cytoplasmic NF- $\kappa \mathrm{B}$ renders it inactive and thereby prevents and trafficking of NF- $\mathrm{KB}$ subunits (RelA and $\mathrm{p} 50$ ) to the nucleus; additionally, IкB also represses postinduction NF- $\mathrm{kB}$ activation through interference on NF- $\mathrm{\kappa B} / \mathrm{DNA}$ binding and subsequent expression of cytokine genes. This is a tightly regulated pathway, and efficient nuclear export of I $\kappa B$ is required for the replenishment of cytoplasmic pools of NF- $\kappa B / I \kappa B$ complexes and subsequent regulation of NF- $\mathrm{KB}$ activation. The inhibition of CRM1 export results in nuclear retention I $\mathrm{kB}$ and NF- $\mathrm{kB}$ subunits, thus leading to inactivation of NF- $\mathrm{KB}$ signaling [220,222-224]. We have observed nuclear accumulation of NF-kB subunits following KPT-335 treatment in RSV and IAV infected cells, as compared to a mock-treated control. NF- $\mathrm{KB}$ activation has been shown to correlate with disease severity in influenza and RSV infections, along with countless other infectious pathogens, through the upregulation of pro-inflammatory cytokines and infiltration of immune cell to sites of infections (Figure 4) [146-149,156].

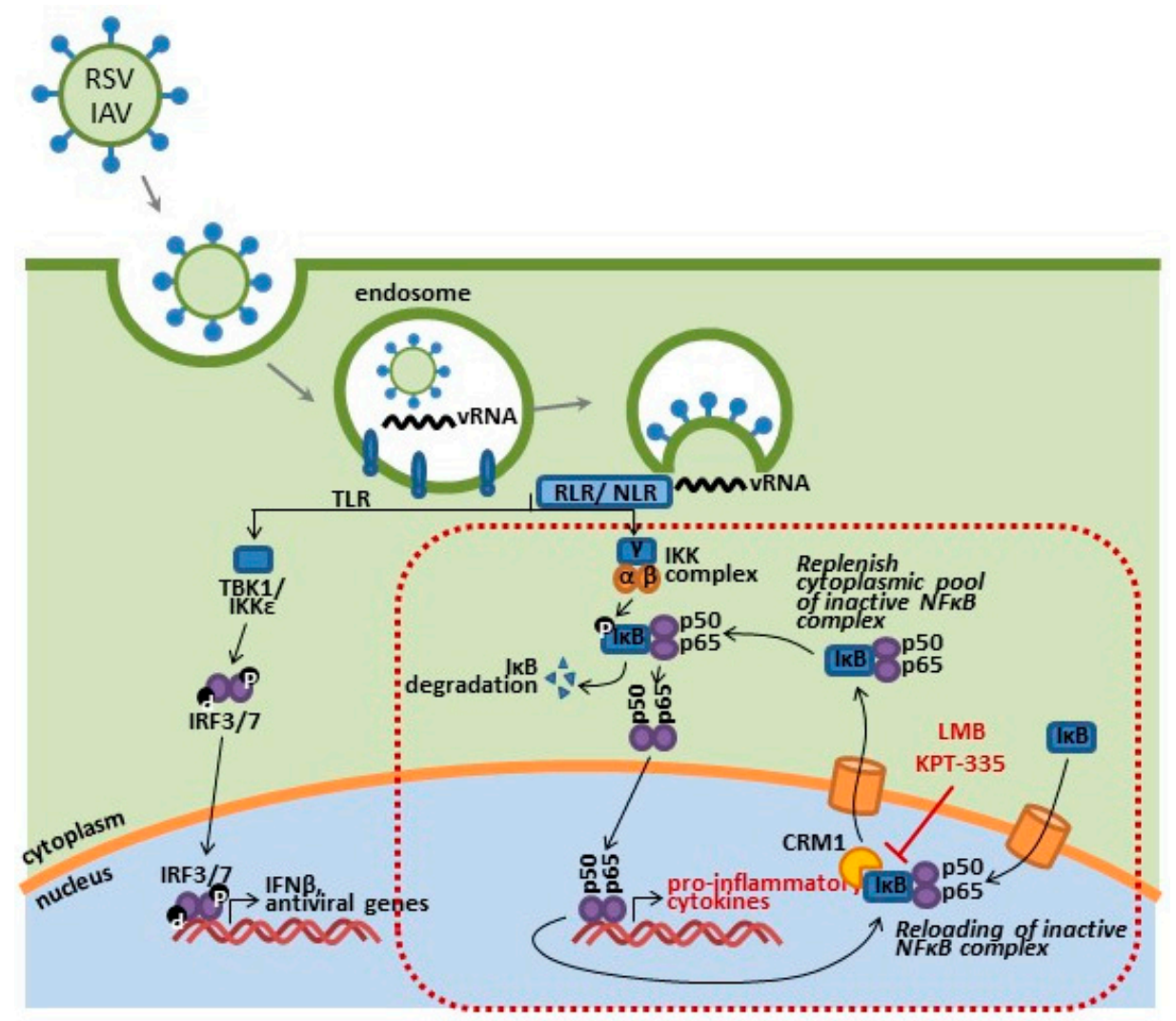

Figure 4. Respiratory syncytial virus (RSV) and influenza A virus (IAV) ssRNA and dsRNA moieties are detected by PPRs, triggering the downstream production of pro-inflammatory and interferon responses. KPT-SINE compounds may also act as immunomodulatory drugs disrupting the activation and regulation of I $\mathrm{KB}$ (inhibitor of NF- $\mathrm{kB}$ ), as well as other transcriptional factors initiated during viral infection.

\section{Conclusions}

The influenza virus and RSV are a major public health concern. It is clear that a different approach needs to be considered to combat outbreaks and reduce the burden of these respiratory pathogens. SINE compounds are well tolerated, orally bioavailable drugs that may provide solutions to the outstanding issues with currently available antivirals, such as drug resistance, poor tolerability and reduced efficacy. SINE targeting of CRM1 could have a dual therapeutic effect: (1) repressing of the NF- $\mathrm{kB}$ dependent cytokine response and elimination of virus-associated immunopathology; and (2) reduction in the nuclear export of critical viral protein(s), thereby attenuating late stage virus 
replication processes. Our preliminary studies have provided the initial framework for future human clinical evaluations of KPT-335 as an antiviral against RSV and influenza virus. Given that many viruses utilize the nucleus as part of their viral life cycle, KPT-335 inhibition of CRM1-mediated export could be effective against a number other viruses, including human immunodeficiency virus (HIV), Hepatitis B, Hepatitis C, and Herpes simplex viruses [182]. The repurposing of SINE compounds from cancer chemotherapeutics to safe and effective antivirals and anti-inflammatory drugs increases the therapeutic potential of these compounds.

Acknowledgments: We would like to thank Kevin J. Polach for his critical review of the manuscript and Olivia Perwitasari for contributing to the creation of the images utilized in this manuscript. These studies were supported by the National Institutes of Health Exploratory/Developmental Grant (R21AI119903) and National Institute of Allergy and Infectious Diseases Grant (HHSN266200700006C), along with funding from the Georgia Research Alliance.

Author Contributions: This manuscript was written by Jennifer A. Pickens and Ralph A. Tripp.

Conflicts of Interest: The authors declare no conflict of interest.

\section{References}

1. World Health Organization (WHO). Influenza (Seasonal) Factsheet $n^{\circ}$ 12; WHO: Geneva, Switzerland, 2016.

2. Thompson, W.W.; Shay, D.K.; Weintraub, E.; Brammer, L.; Cox, N.; Anderson, L.J.; Fukuda, K. Mortality associated with influenza and respiratory syncytial virus in the United States. J. Am. Med. Assoc. 2003, 289, 179-186. [CrossRef]

3. Bian, J.R.; Nie, W.; Zang, Y.S.; Fang, Z.; Xiu, Q.Y.; Xu, X.X. Clinical aspects and cytokine response in adults with seasonal influenza infection. Int. J. Clin. Exp. Med. 2014, 7, 5593-5602. [PubMed]

4. Eccles, R. Understanding the symptoms of the common cold and influenza. Lancet Infect. Dis. 2005, 5, 718-725. [CrossRef]

5. Elliot, A.J.; Fleming, D.M. Influenza and respiratory syncytial virus in the elderly. Expert Rev. Vaccines 2008, 7, 249-258. [CrossRef] [PubMed]

6. Hall, C.B.; Weinberg, G.A.; Blumkin, A.K.; Edwards, K.M.; Staat, M.A.; Schultz, A.F.; Poehling, K.A.; Szilagyi, P.G.; Griffin, M.R.; Williams, J.V.; et al. Respiratory syncytial virus-associated hospitalizations among children less than 24 months of age. Pediatrics 2013, 132, e341-e348. [CrossRef] [PubMed]

7. Iwane, M.K.; Edwards, K.M.; Szilagyi, P.G.; Walker, F.J.; Griffin, M.R.; Weinberg, G.A.; Coulen, C.; Poehling, K.A.; Shone, L.P.; Balter, S.; et al. Population-based surveillance for hospitalizations associated with respiratory syncytial virus, influenza virus, and parainfluenza viruses among young children. Pediatrics 2004, 113, 1758-1764. [CrossRef] [PubMed]

8. Shi, T.; McAllister, D.A.; O’Brien, K.L.; Simoes, E.A.F.; Madhi, S.A.; Gessner, B.D.; Polack, F.P.; Balsells, E.; Acacio, S.; Aguayo, C.; et al. Global, regional, and national disease burden estimates of acute lower respiratory infections due to respiratory syncytial virus in young children in 2015: A systematic review and modelling study. Lancet 2017, 390, 946-958. [CrossRef]

9. Falsey, A.R.; Hennessey, P.A.; Formica, M.A.; Cox, C.; Walsh, E.E. Respiratory syncytial virus infection in elderly and high-risk adults. N. Engl. J. Med. 2005, 352, 1749-1759. [CrossRef] [PubMed]

10. Falsey, A.R.; Walsh, E.E. Respiratory syncytial virus infection in elderly adults. Drugs Aging 2005, 22, 577-587. [CrossRef] [PubMed]

11. Chutiwitoonchai, N.; Mano, T.; Kakisaka, M.; Sato, H.; Kondoh, Y.; Osada, H.; Kotani, O.; Yokoyama, M.; Sato, H.; Aida, Y. Inhibition of CRM1-mediated nuclear export of influenza a nucleoprotein and nuclear export protein as a novel target for antiviral drug development. Virology 2017, 507, 32-39. [CrossRef] [PubMed]

12. Ghildyal, R.; Ho, A.; Dias, M.; Soegiyono, L.; Bardin, P.G.; Tran, K.C.; Teng, M.N.; Jans, D.A. The respiratory syncytial virus matrix protein possesses a CRM1-mediated nuclear export mechanism. J. Virol. 2009, 83, 5353-5362. [CrossRef] [PubMed]

13. Neumann, G.; Hughes, M.T.; Kawaoka, Y. Influenza a virus NS2 protein mediates VRNP nuclear export through NES-independent interaction with HCRM1. EMBO J. 2000, 19, 6751-6758. [CrossRef] [PubMed] 
14. Perwitasari, O.; Johnson, S.; Yan, X.; Howerth, E.; Shacham, S.; Landesman, Y.; Baloglu, E.; McCauley, D.; Tamir, S.; Tompkins, S.M.; et al. Verdinexor, a novel selective inhibitor of nuclear export, reduces influenza a virus replication in vitro and in vivo. J. Virol. 2014, 88, 10228-10243. [CrossRef] [PubMed]

15. Jones, I.M.; Reay, P.A.; Philpott, K.L. Nuclear location of all three influenza polymerase proteins and a nuclear signal in polymerase PB2. EMBO J. 1986, 5, 2371-2376. [PubMed]

16. Eisfeld, A.J.; Neumann, G.; Kawaoka, Y. At the centre: Influenza A virus ribonucleoproteins. Nat. Rev. Microbiol. 2015, 13, 28-41. [CrossRef] [PubMed]

17. Neumann, G.; Castrucci, M.R.; Kawaoka, Y. Nuclear import and export of influenza virus nucleoprotein. J. Virol. 1997, 71, 9690-9700. [PubMed]

18. O'Neill, R.E.; Jaskunas, R.; Blobel, G.; Palese, P.; Moroianu, J. Nuclear import of influenza virus RNA can be mediated by viral nucleoprotein and transport factors required for protein import. J. Biol. Chem. 1995, 270, 22701-22704. [CrossRef] [PubMed]

19. Yoon, S.W.; Webby, R.J.; Webster, R.G. Evolution and ecology of influenza A viruses. Curr. Top. Microbiol. Immunol. 2014, 385, 359-375. [PubMed]

20. Webster, R.G.; Bean, W.J.; Gorman, O.T.; Chambers, T.M.; Kawaoka, Y. Evolution and ecology of influenza A viruses. Microbiol. Rev. 1992, 56, 152-179. [PubMed]

21. Wu, Y.; Wu, Y.; Tefsen, B.; Shi, Y.; Gao, G.F. Bat-derived influenza-like viruses H17N10 and H18N11. Trends Microbiol. 2014, 22, 183-191. [CrossRef] [PubMed]

22. Rogers, G.N.; Paulson, J.C.; Daniels, R.S.; Skehel, J.J.; Wilson, I.A.; Wiley, D.C. Single amino acid substitutions in influenza haemagglutinin change receptor binding specificity. Nature 1983, 304, 76-78. [CrossRef] [PubMed]

23. Rogers, G.N.; Pritchett, T.J.; Lane, J.L.; Paulson, J.C. Differential sensitivity of human, avian, and equine influenza A viruses to a glycoprotein inhibitor of infection: Selection of receptor specific variants. Virology 1983, 131, 394-408. [CrossRef]

24. Ma, K.; Roy, A.M.M.; Whittaker, G.R. Nuclear export of influenza virus ribonucleoproteins: Identification of an export intermediate at the nuclear periphery. Virology 2001, 282, 215-220. [CrossRef] [PubMed]

25. Sieczkarski, S.B.; Whittaker, G.R. Viral entry. Curr. Top. Microbiol. 2005, 285, 1-23.

26. Whittaker, G.R.; Kann, M.; Helenius, A. Viral entry into the nucleus. Annu. Rev. Cell Dev. Biol. 2000, 16, 627-651. [CrossRef] [PubMed]

27. Pinto, L.H.; Holsinger, L.J.; Lamb, R.A. Influenza virus M2 protein has ion channel activity. Cell 1992, 69, 517-528. [CrossRef]

28. Shimbo, K.; Brassard, D.L.; Lamb, R.A.; Pinto, L.H. Ion selectivity and activation of the M2 ion channel of influenza virus. Biophys. J. 1996, 70, 1335-1346. [CrossRef]

29. Wang, C.; Lamb, R.A.; Pinto, L.H. Activation of the M2 ion channel of influenza virus: A role for the transmembrane domain histidine residue. Biophys. J. 1995, 69, 1363-1371. [CrossRef]

30. Moroianu, J.; Hijikata, M.; Blobel, G.; Radu, A. Mammalian karyopherin $\alpha_{1} \beta$ and $\alpha_{2} \beta$ heterodimers: $\alpha_{1}$ or $\alpha_{2}$ subunit binds nuclear localization signal and $\beta$ subunit interacts with peptide repeat-containing nucleoporins. Proc. Natl. Acad. Sci. USA 1995, 92, 6532-6536. [CrossRef] [PubMed]

31. Radu, A.; Blobel, G.; Moore, M.S. Identification of a protein complex that is required for nuclear protein import and mediates docking of import substrate to distinct nucleoporins. Proc. Natl. Acad. Sci. USA 1995, 92, 1769-1773. [CrossRef] [PubMed]

32. Nieto, A.; de la Luna, S.; Barcena, J.; Portela, A.; Ortin, J. Complex structure of the nuclear translocation signal of influenza virus polymerase PAa subunit. J. Gen. Virol. 1994, 75, 29-36. [CrossRef] [PubMed]

33. Akkina, R.K.; Chambers, T.M.; Londo, D.R.; Nayak, D.P. Intracellular localization of the viral polymerase proteins in cells infected with influenza virus and cells expressing PB1 protein from cloned cDNA. J. Virol. 1987, 61, 2217-2224. [PubMed]

34. Elton, D.; Simpson-Holley, M.; Archer, K.; Medcalf, L.; Hallam, R.; McCauley, J.; Digard, P. Interaction of the influenza virus nucleoprotein with the cellular CRM1-mediated nuclear export pathway. J. Virol. 2001, 75, 408-419. [CrossRef] [PubMed]

35. Martin, K.; Helenius, A. Nuclear transport of influenza virus ribonucleoproteins: The viral matrix protein (M1) promotes export and inhibits import. Cell 1991, 67, 117-130. [CrossRef]

36. Bui, M.; Wills, E.G.; Helenius, A.; Whittaker, G.R. Role of the influenza virus M1 protein in nuclear export of viral ribonucleoproteins. J. Virol. 2000, 74, 1781-1786. [CrossRef] [PubMed] 
37. Rima, B.; Collins, P.; Easton, A.; Fouchier, R.; Kurath, G.; Lamb, R.A.; Lee, B.; Maisner, A.; Rota, P.; Wang, L.; et al. ICTV virus taxonomy profile: Pneumoviridae. J. Gen. Virol. 2017, 98, 2912-2913. [CrossRef] [PubMed]

38. Garcia, J.; Garcia-Barreno, B.; Vivo, A.; Melero, J.A. Cytoplasmic inclusions of respiratory syncytial virus-infected cells: Formation of inclusion bodies in transfected cells that coexpress the nucleoprotein, the phosphoprotein, and the 22K protein. Virology 1993, 195, 243-247. [CrossRef] [PubMed]

39. Li, D.; Jans, D.A.; Bardin, P.G.; Meanger, J.; Mills, J.; Ghildyal, R. Association of respiratory syncytial virus M protein with viral nucleocapsids is mediated by the M2-1 protein. J. Virol. 2008, 82, 8863-8870. [CrossRef] [PubMed]

40. Zhao, X.; Singh, M.; Malashkevich, V.N.; Kim, P.S. Structural characterization of the human respiratory syncytial virus fusion protein core. Proc. Natl. Acad. Sci. USA 2000, 97, 14172-14177. [CrossRef] [PubMed]

41. Roberts, S.R.; Lichtenstein, D.; Ball, L.A.; Wertz, G.W. The membrane-associated and secreted forms of the respiratory syncytial virus attachment glycoprotein $\mathrm{G}$ are synthesized from alternative initiation codons. J. Virol. 1994, 68, 4538-4546. [PubMed]

42. Pickles, R.J. Human airway epithelial cell cultures for modeling respiratory syncytial virus infection. Curr. Top. Microbiol. Immunol. 2013, 372, 371-387. [PubMed]

43. Zhang, L.; Peeples, M.E.; Boucher, R.C.; Collins, P.L.; Pickles, R.J. Respiratory syncytial virus infection of human airway epithelial cells is polarized, specific to ciliated cells, and without obvious cytopathology. J. Virol. 2002, 76, 5654-5666. [CrossRef] [PubMed]

44. Villenave, R.; Thavagnanam, S.; Sarlang, S.; Parker, J.; Douglas, I.; Skibinski, G.; Heaney, L.G.; McKaigue, J.P.; Coyle, P.V.; Shields, M.D.; et al. In vitro modeling of respiratory syncytial virus infection of pediatric bronchial epithelium, the primary target of infection in vivo. Proc. Natl. Acad. Sci. USA 2012, 109, 5040-5045. [CrossRef] [PubMed]

45. Oshansky, C.M.; Zhang, W.; Moore, E.; Tripp, R.A. The host response and molecular pathogenesis associated with respiratory syncytial virus infection. Future Microbiol. 2009, 4, 279-297. [CrossRef] [PubMed]

46. San-Juan-Vergara, H.; Sampayo-Escobar, V.; Reyes, N.; Cha, B.; Pacheco-Lugo, L.; Wong, T.; Peeples, M.E.; Collins, P.L.; Castano, M.E.; Mohapatra, S.S. Cholesterol-rich microdomains as docking platforms for respiratory syncytial virus in normal human bronchial epithelial cells. J. Virol. 2012, 86, 1832-1843. [CrossRef] [PubMed]

47. Tayyari, F.; Marchant, D.; Moraes, T.J.; Duan, W.M.; Mastrangelo, P.; Hegele, R.G. Identification of nucleolin as a cellular receptor for human respiratory syncytial virus. Nat. Med. 2011, 17, 1132-1135. [CrossRef] [PubMed]

48. Ghildyal, R.; Baulch-Brown, C.; Mills, J.; Meanger, J. The matrix protein of human respiratory syncytial virus localises to the nucleus of infected cells and inhibits transcription. Arch. Virol. 2003, 148, 1419-1429. [PubMed]

49. Ghildyal, R.; Mills, J.; Murray, M.; Vardaxis, N.; Meanger, J. Respiratory syncytial virus matrix protein associates with nucleocapsids in infected cells. J. Gen. Virol. 2002, 83, 753-757. [CrossRef] [PubMed]

50. Ghildyal, R.; Ho, A.; Wagstaff, K.M.; Dias, M.M.; Barton, C.L.; Jans, P.; Bardin, P.; Jans, D.A. Nuclear import of the respiratory syncytial virus matrix protein is mediated by importin $\beta_{1}$ independent of importin $\alpha$. Biochemistry 2005, 44, 12887-12895. [CrossRef] [PubMed]

51. Schnell, J.R.; Chou, J.J. Structure and mechanism of the M2 proton channel of influenza A virus. Nature 2008, 451, 591-595. [CrossRef] [PubMed]

52. Centers for Disease Control and Prevention (CDC). Influenza Antiviral Drug Resistance Fact Sheet; CDC: Atlanta, GA, USA, 2017.

53. Rungrotmongkol, T.; Intharathep, P.; Malaisree, M.; Nunthaboot, N.; Kaiyawet, N.; Sompornpisut, P.; Payungporn, S.; Poovorawan, Y.; Hannongbua, S. Susceptibility of antiviral drugs against 2009 influenza A (H1N1) virus. Biochem. Biophys. Res. Commun. 2009, 385, 390-394. [CrossRef] [PubMed]

54. Deyde, V.M.; Xu, X.; Bright, R.A.; Shaw, M.; Smith, C.B.; Zhang, Y.; Shu, Y.; Gubareva, L.V.; Cox, N.J.; Klimov, A.I. Surveillance of resistance to adamantanes among influenza A(H3N2) and A(H1N1) viruses isolated worldwide. J. Infect. Dis. 2007, 196, 249-257. [CrossRef] [PubMed]

55. Von Itzstein, M.; Wu, W.Y.; Kok, G.B.; Pegg, M.S.; Dyason, J.C.; Jin, B.; Van Phan, T.; Smythe, M.L.; White, H.F.; Oliver, S.W.; et al. Rational design of potent sialidase-based inhibitors of influenza virus replication. Nature 1993, 363, 418-423. [CrossRef] [PubMed] 
56. McKimm-Breschkin, J.L. Influenza neuraminidase inhibitors: Antiviral action and mechanisms of resistance. Influenza Respir. Viruses 2013, 7 (Suppl. 1), 25-36. [CrossRef] [PubMed]

57. Kim, C.U.; Lew, W.; Williams, M.A.; Liu, H.; Zhang, L.; Swaminathan, S.; Bischofberger, N.; Chen, M.S.; Mendel, D.B.; Tai, C.Y.; et al. Influenza neuraminidase inhibitors possessing a novel hydrophobic interaction in the enzyme active site: Design, synthesis, and structural analysis of carbocyclic sialic acid analogues with potent anti-influenza activity. J. Am. Chem. Soc. 1997, 119, 681-690. [CrossRef] [PubMed]

58. Aoki, F.Y.; Hayden, F.G.; Zanamivir. A potent and selective inhibitor of influenza A and B viruses. Clin. Pharmacokinet. 1999, 36, v-ix. [PubMed]

59. Hayden, F.G.; Atmar, R.L.; Schilling, M.; Johnson, C.; Poretz, D.; Paar, D.; Huson, L.; Ward, P.; Mills, R.G. Use of the selective oral neuraminidase inhibitor oseltamivir to prevent influenza. N. Engl. J. Med. 1999, 341, 1336-1343. [CrossRef] [PubMed]

60. Hayden, F.G.; Treanor, J.J.; Fritz, R.S.; Lobo, M.; Betts, R.F.; Miller, M.; Kinnersley, N.; Mills, R.G.; Ward, P.; Straus, S.E. Use of the oral neuraminidase inhibitor oseltamivir in experimental human influenza: Randomized controlled trials for prevention and treatment. J. Am. Med. Assoc. 1999, 282, 1240-1246. [CrossRef]

61. Gillissen, A.; Hoffken, G. Early therapy with the neuraminidase inhibitor oseltamivir maximizes its efficacy in influenza treatment. Med. Microbiol. Immunol. 2002, 191, 165-168. [CrossRef] [PubMed]

62. Fleming, D.M. Influenza diagnosis and treatment: A view from clinical practice. Philos. Trans. R. Soc. Lond. B Biol. Sci. 2001, 356, 1933-1943. [PubMed]

63. Kandel, R.; Hartshorn, K.L. Prophylaxis and treatment of influenza virus infection. BioDrugs 2001, 15, 303-323. [CrossRef] [PubMed]

64. Sheu, T.G.; Deyde, V.M.; Okomo-Adhiambo, M.; Garten, R.J.; Xu, X.; Bright, R.A.; Butler, E.N.; Wallis, T.R.; Klimov, A.I.; Gubareva, L.V. Surveillance for neuraminidase inhibitor resistance among human influenza A and B viruses circulating worldwide from 2004 to 2008. Antimicrob. Agents Chemother. 2008, 52, 3284-3292. [CrossRef] [PubMed]

65. Paules, C.I.; Sullivan, S.G.; Subbarao, K.; Fauci, A.S. Chasing seasonal influenza-The need for a universal influenza vaccine. N. Engl. J. Med. 2017, 378, 7-9. [CrossRef] [PubMed]

66. Govorkova, E.A.; Leneva, I.A.; Goloubeva, O.G.; Bush, K.; Webster, R.G. Comparison of efficacies of RWJ-270201, zanamivir, and oseltamivir against H5N1, H9N2, and other avian influenza viruses. Antimicrob. Agents Chemother. 2001, 45, 2723-2732. [CrossRef] [PubMed]

67. Alame, M.M.; Massaad, E.; Zaraket, H. Peramivir: A novel intravenous neuraminidase inhibitor for treatment of acute influenza infections. Front. Microbiol. 2016, 7, 450. [CrossRef] [PubMed]

68. Babu, Y.S.; Chand, P.; Bantia, S.; Kotian, P.; Dehghani, A.; El-Kattan, Y.; Lin, T.H.; Hutchison, T.L.; Elliott, A.J.; Parker, C.D.; et al. BCX-1812 (RWJ-270201): Discovery of a novel, highly potent, orally active, and selective influenza neuraminidase inhibitor through structure-based drug design. J. Med. Chem. 2000, 43, 3482-3486. [CrossRef] [PubMed]

69. Ishizuka, H.; Toyama, K.; Yoshiba, S.; Okabe, H.; Furuie, H. Intrapulmonary distribution and pharmacokinetics of laninamivir, a neuraminidase inhibitor, after a single inhaled administration of its prodrug, laninamivir octanoate, in healthy volunteers. Antimicrob. Agents Chemother. 2012, 56, 3873-3878. [CrossRef] [PubMed]

70. Kashiwagi, S.; Watanabe, A.; Ikematsu, H.; Awamura, S.; Okamoto, T.; Uemori, M.; Ishida, K. Laninamivir octanoate for post-exposure prophylaxis of influenza in household contacts: A randomized double blind placebo controlled trial. J. Infect. Chemother. 2013, 19, 740-749. [CrossRef] [PubMed]

71. Kubo, S.; Tomozawa, T.; Kakuta, M.; Tokumitsu, A.; Yamashita, M. Laninamivir prodrug CS-8958, a long-acting neuraminidase inhibitor, shows superior anti-influenza virus activity after a single administration. Antimicrob. Agents Chemother. 2010, 54, 1256-1264. [CrossRef] [PubMed]

72. Reviriego, C. Laninamivir octanoate neuraminidase inhibitor treatment of influenza. Drugs Future 2010, 35, 537-545. [CrossRef]

73. Samson, M.; Abed, Y.; Desrochers, F.M.; Hamilton, S.; Luttick, A.; Tucker, S.P.; Pryor, M.J.; Boivin, G. Characterization of drug-resistant influenza virus $\mathrm{A}(\mathrm{H} 1 \mathrm{~N} 1)$ and $\mathrm{A}(\mathrm{H} 3 \mathrm{~N} 2)$ variants selected in vitro with laninamivir. Antimicrob. Agents Chemother. 2014, 58, 5220-5228. [CrossRef] [PubMed] 
74. Watanabe, A.; Chang, S.C.; Kim, M.J.; Chu, D.W.; Ohashi, Y.; Group, M.S. Long-acting neuraminidase inhibitor laninamivir octanoate versus oseltamivir for treatment of influenza: A double-blind, randomized, noninferiority clinical trial. Clin. Infect. Dis. 2010, 51, 1167-1175. [CrossRef] [PubMed]

75. Tricco, A.C.; Chit, A.; Soobiah, C.; Hallett, D.; Meier, G.; Chen, M.H.; Tashkandi, M.; Bauch, C.T.; Loeb, M. Comparing influenza vaccine efficacy against mismatched and matched strains: A systematic review and meta-analysis. BMC Med. 2013, 11, 153. [CrossRef] [PubMed]

76. Krammer, F.; Pica, N.; Hai, R.; Margine, I.; Palese, P. Chimeric hemagglutinin influenza virus vaccine constructs elicit broadly protective stalk-specific antibodies. J. Virol. 2013, 87, 6542-6550. [CrossRef] [PubMed]

77. Margine, I.; Krammer, F.; Hai, R.; Heaton, N.S.; Tan, G.S.; Andrews, S.A.; Runstadler, J.A.; Wilson, P.C.; Albrecht, R.A.; Garcia-Sastre, A.; et al. Hemagglutinin stalk-based universal vaccine constructs protect against group 2 influenza A viruses. J. Virol. 2013, 87, 10435-10446. [CrossRef] [PubMed]

78. Steel, J.; Lowen, A.C.; Wang, T.T.; Yondola, M.; Gao, Q.; Haye, K.; Garcia-Sastre, A.; Palese, P. Influenza virus vaccine based on the conserved hemagglutinin stalk domain. mBio 2010, 1, e00018-10. [CrossRef] [PubMed]

79. Yassine, H.M.; Boyington, J.C.; McTamney, P.M.; Wei, C.J.; Kanekiyo, M.; Kong, W.P.; Gallagher, J.R.; Wang, L.; Zhang, Y.; Joyce, M.G.; et al. Hemagglutinin-stem nanoparticles generate heterosubtypic influenza protection. Nat. Med. 2015, 21, 1065-1070. [CrossRef] [PubMed]

80. He, W.Q.; Tan, G.S.; Mullarkey, C.E.; Lee, A.J.; Lam, M.M.W.; Krammer, F.; Henry, C.; Wilson, P.C.; Ashkar, A.A.; Palese, P.; et al. Epitope specificity plays a critical role in regulating antibody-dependent cell-mediated cytotoxicity against influenza A virus. Proc. Natl. Acad. Sci. USA 2016, 113, 11931-11936. [CrossRef] [PubMed]

81. Sanchez-Solis de Querol, M.; Castillo-Ochando, F.; Diaz-Torres, M.; Sayed-Sancho, N.; Sanchez-Flores, F.; Pajaron de Ahumada, M. Ribavirin in the treatment of bronchiolitis caused by syncytial respiratory virus. An. Espan. Pediatr. 1997, 47, 14-16. (In Spanish)

82. Johnson, S.; Oliver, C.; Prince, G.A.; Hemming, V.G.; Pfarr, D.S.; Wang, S.C.; Dormitzer, M.; O'Grady, J.; Koenig, S.; Tamura, J.K.; et al. Development of a humanized monoclonal antibody (MEDI-493) with potent in vitro and in vivo activity against respiratory syncytial virus. J. Infect. Dis. 1997, 176, 1215-1224. [CrossRef] [PubMed]

83. Patterson, J.L.; Fernandez-Larsson, R. Molecular mechanisms of action of ribavirin. Rev. Infect. Dis. 1990, 12, 1139-1146. [CrossRef] [PubMed]

84. Sharland, M.; Whitehouse, N.; Qureshi, S. Ribavirin in respiratory syncytial virus infection. Arch. Dis. Child. 1989, 64, 425. [CrossRef] [PubMed]

85. Berger, K.L.; Scherer, J.; Ranga, M.; Sha, N.; Stern, J.O.; Quinson, A.M.; Kukolj, G. Baseline polymorphisms and emergence of drug resistance in the NS3/4A protease of hepatitis c virus genotype 1 following treatment with faldaprevir and pegylated interferon $\alpha 2 \mathrm{a} /$ Ribavirin in phase 2 and phase 3 studies. Antimicrob. Agents Chemother. 2015, 59, 6017-6025. [CrossRef] [PubMed]

86. Hayashi, K.; Ishigami, M.; Ishizu, Y.; Kuzuya, T.; Honda, T.; Katano, Y.; Hirooka, Y.; Goto, H. Drug resistance mutations in the NS3 and NS5A regions in patients with hepatitis C virus genotype 1B and response to telaprevir plus pegylated-interferon- $\alpha$ 2B and ribavirin combination therapy. Gastroenterology 2014, 146, S979. [CrossRef]

87. Adams, O.; Bonzel, L.; Kovacevic, A.; Mayatepek, E.; Hoehn, T.; Vogel, M. Palivizumab-resistant human respiratory syncytial virus infection in infancy. Clin. Infect. Dis. 2010, 51, 185-188. [CrossRef] [PubMed]

88. Heylen, E.; Neyts, J.; Jochmans, D. Drug candidates and model systems in respiratory syncytial virus antiviral drug discovery. Biochem. Pharmacol. 2017, 127, 1-12. [CrossRef] [PubMed]

89. Liss, H.P.; Bernstein, J. Ribavirin aerosol in the elderly. Chest 1988, 93, 1239-1241. [CrossRef] [PubMed]

90. Wright, P.F. Progress in the prevention and treatment of RSV infection. N. Engl. J. Med. 2014, 371, 776-777. [CrossRef] [PubMed]

91. Kapikian, A.Z.; Mitchell, R.H.; Chanock, R.M.; Shvedoff, R.A.; Stewart, C.E. An epidemiologic study of altered clinical reactivity to respiratory syncytial (RS) virus infection in children previously vaccinated with an inactivated RS virus vaccine. Am. J. Epidemiol. 1969, 89, 405-421. [CrossRef] [PubMed]

92. Kim, H.W.; Canchola, J.G.; Brandt, C.D.; Pyles, G.; Chanock, R.M.; Jensen, K.; Parrott, R.H. Respiratory syncytial virus disease in infants despite prior administration of antigenic inactivated vaccine. Am. J. Epidemiol. 1969, 89, 422-434. [CrossRef] [PubMed] 
93. Mazur, N.I.; Martinon-Torres, F.; Baraldi, E.; Fauroux, B.; Greenough, A.; Heikkinen, T.; Manzoni, P.; Mejias, A.; Nair, H.; Papadopoulos, N.G.; et al. Lower respiratory tract infection caused by respiratory syncytial virus: Current management and new therapeutics. Lancet Respir. Med. 2015, 3, 888-900. [CrossRef]

94. Papadopoulos, N.G.; Megremis, S.; Kitsioulis, N.A.; Vangelatou, O.; West, P.; Xepapadaki, P. Promising approaches for the treatment and prevention of viral respiratory illnesses. J. Allergy Clin. Immunol. 2017, 140, 921-932. [CrossRef] [PubMed]

95. Fries, L.; Shinde, V.; Stoddard, J.J.; Thomas, D.N.; Kpamegan, E.; Lu, H.; Smith, G.; Hickman, S.P.; Piedra, P.; Glenn, G.M. Immunogenicity and safety of a respiratory syncytial virus fusion protein (RSV F) nanoparticle vaccine in older adults. Immun. Ageing 2017, 14, 8. [CrossRef] [PubMed]

96. Glenn, G.M.; Smith, G.; Fries, L.; Raghunandan, R.; Lu, H.; Zhou, B.; Thomas, D.N.; Hickman, S.P.; Kpamegan, E.; Boddapati, S.; et al. Safety and immunogenicity of a SF9 insect cell-derived respiratory syncytial virus fusion protein nanoparticle vaccine. Vaccine 2013, 31, 524-532. [CrossRef] [PubMed]

97. Rezaee, F.; Linfield, D.T.; Harford, T.J.; Piedimonte, G. Ongoing developments in RSV prophylaxis: A clinician's analysis. Curr. Opin. Virol. 2017, 24, 70-78. [CrossRef] [PubMed]

98. Yan, D.; Lee, S.; Thakkar, V.D.; Luo, M.; Moore, M.L.; Plemper, R.K. Cross-resistance mechanism of respiratory syncytial virus against structurally diverse entry inhibitors. Proc. Natl. Acad. Sci. USA 2014, 111, E3441-E3449. [CrossRef] [PubMed]

99. Laganas, V.A.; Dunn, E.F.; McLaughlin, R.E.; Tiong-Yip, C.L.; Yuzhakov, O.; Isabella, V.M.; Hill, P.; Yu, Q. Characterization of novel respiratory syncytial virus inhibitors identified by high throughput screen. Antivir. Res. 2015, 115, 71-74. [CrossRef] [PubMed]

100. Shook, B.C.; Lin, K. Recent advances in developing antiviral therapies for respiratory syncytial virus. Top. Curr. Chem. (Cham) 2017, 375, 40. [CrossRef] [PubMed]

101. Jorquera, P.A.; Tripp, R.A. Respiratory syncytial virus: Prospects for new and emerging therapeutics. Expert Rev. Respir. Med. 2017, 11, 609-615. [CrossRef] [PubMed]

102. Mackman, R.L.; Sangi, M.; Sperandio, D.; Parrish, J.P.; Eisenberg, E.; Perron, M.; Hui, H.; Zhang, L.; Siegel, D.; Yang, H.; et al. Discovery of an oral respiratory syncytial virus (RSV) fusion inhibitor (GS-5806) and clinical proof of concept in a human RSV challenge study. J. Med. Chem. 2015, 58, 1630-1643. [CrossRef] [PubMed]

103. Perron, M.; Stray, K.; Kinkade, A.; Theodore, D.; Lee, G.; Eisenberg, E.; Sangi, M.; Gilbert, B.E.; Jordan, R.; Piedra, P.A.; et al. GS-5806 inhibits a broad range of respiratory syncytial virus clinical isolates by blocking the virus-cell fusion process. Antimicrob. Agents Chemother. 2015, 60, 1264-1273. [CrossRef] [PubMed]

104. Samuel, D.; Xing, W.; Niedziela-Majka, A.; Wong, J.S.; Hung, M.; Brendza, K.M.; Perron, M.; Jordan, R.; Sperandio, D.; Liu, X.; et al. GS-5806 inhibits pre- to postfusion conformational changes of the respiratory syncytial virus fusion protein. Antimicrob. Agents Chemother. 2015, 59, 7109-7112. [CrossRef] [PubMed]

105. Kimura, K.; Ishioka, K.; Hashimoto, K.; Mori, S.; Suzutani, T.; Bowlin, T.L.; Shigeta, S. Isolation and characterization of NMSO3-resistant mutants of respiratory syncytial virus. Antivir. Res. 2004, 61, 165-171. [CrossRef] [PubMed]

106. Kimura, K.; Mori, S.; Tomita, K.; Ohno, K.; Takahashi, K.; Shigeta, S.; Terada, M. Antiviral activity of NMSO3 against respiratory syncytial virus infection in vitro and in vivo. Antivir. Res. 2000, 47, 41-51. [CrossRef]

107. Challa, S.; Scott, A.D.; Yuzhakov, O.; Zhou, Y.; Tiong-Yip, C.L.; Gao, N.; Thresher, J.; Yu, Q. Mechanism of action for respiratory syncytial virus inhibitor RSV604. Antimicrob. Agents Chemother. 2015, 59, 1080-1087. [CrossRef] [PubMed]

108. Chapman, J.; Abbott, E.; Alber, D.G.; Baxter, R.C.; Bithell, S.K.; Henderson, E.A.; Carter, M.C.; Chambers, P.; Chubb, A.; Cockerill, G.S.; et al. RSV604, a novel inhibitor of respiratory syncytial virus replication. Antimicrob. Agents Chemother. 2007, 51, 3346-3353. [CrossRef] [PubMed]

109. Douglas, J.L.; Panis, M.L.; Ho, E.; Lin, K.Y.; Krawczyk, S.H.; Grant, D.M.; Cai, R.; Swaminathan, S.; Chen, X.; Cihlar, T. Small molecules VP-14637 and JNJ-2408068 inhibit respiratory syncytial virus fusion by similar mechanisms. Antimicrob. Agents Chemother. 2005, 49, 2460-2466. [CrossRef] [PubMed]

110. Douglas, J.L.; Panis, M.L.; Ho, E.; Lin, K.Y.; Krawczyk, S.H.; Grant, D.M.; Cai, R.; Swaminathan, S.; Cihlar, T. Inhibition of respiratory syncytial virus fusion by the small molecule VP-14637 via specific interactions with f protein. J. Virol. 2003, 77, 5054-5064. [CrossRef] [PubMed]

111. McKimm-Breschkin, J. VP-14637 viropharma. Curr. Opin. Investig. Drugs 2000, 1, 425-427. [PubMed] 
112. Noton, S.L.; Nagendra, K.; Dunn, E.F.; Mawhorter, M.E.; Yu, Q.; Fearns, R. Respiratory syncytial virus inhibitor AZ-27 differentially inhibits different polymerase activities at the promoter. J. Virol. 2015, 89, 7786-7798. [CrossRef] [PubMed]

113. DeVincenzo, J.P.; McClure, M.W.; Fry, J. ALS-008176 for respiratory syncytial virus infection. N. Engl. J. Med. 2016, 374, 1391-1392. [PubMed]

114. DeVincenzo, J.P.; McClure, M.W.; Symons, J.A.; Fathi, H.; Westland, C.; Chanda, S.; Lambkin-Williams, R.; Smith, P.; Zhang, Q.; Beigelman, L.; et al. Activity of oral ALS-008176 in a respiratory syncytial virus challenge study. N. Engl. J. Med. 2015, 373, 2048-2058. [CrossRef] [PubMed]

115. Rossignol, J.F. Nitazoxanide: A first-in-class broad-spectrum antiviral agent. Antivir. Res. 2014, 110, 94-103. [CrossRef] [PubMed]

116. Haffizulla, J.; Hartman, A.; Hoppers, M.; Resnick, H.; Samudrala, S.; Ginocchio, C.; Bardin, M.; Rossignol, J.F.; US Nitazoxanide Influenza Clinical Study Group. Effect of nitazoxanide in adults and adolescents with acute uncomplicated influenza: A double-blind, randomised, placebo-controlled, phase 2b/3 trial. Lancet Infect. Dis. 2014, 14, 609-618. [CrossRef]

117. Furuta, Y.; Takahashi, K.; Kuno-Maekawa, M.; Sangawa, H.; Uehara, S.; Kozaki, K.; Nomura, N.; Egawa, H.; Shiraki, K. Mechanism of action of T-705 against influenza virus. Antimicrob. Agents Chemother. 2005, 49, 981-986. [CrossRef] [PubMed]

118. Jin, Z.; Smith, L.K.; Rajwanshi, V.K.; Kim, B.; Deval, J. The ambiguous base-pairing and high substrate efficiency of T-705 (favipiravir) ribofuranosyl 5'-triphosphate towards influenza A virus polymerase. PLoS ONE 2013, 8, e68347. [CrossRef] [PubMed]

119. Boyd, M.J.; Bandarage, U.K.; Bennett, H.; Byrn, R.R.; Davies, I.; Gu, W.; Jacobs, M.; Ledeboer, M.W.; Ledford, B.; Leeman, J.R.; et al. Isosteric replacements of the carboxylic acid of drug candidate VX-787: Effect of charge on antiviral potency and kinase activity of azaindole-based influenza PB2 inhibitors. Bioorg. Med. Chem. Lett. 2015, 25, 1990-1994. [CrossRef] [PubMed]

120. Byrn, R.A.; Jones, S.M.; Bennett, H.B.; Bral, C.; Clark, M.P.; Jacobs, M.D.; Kwong, A.D.; Ledeboer, M.W.; Leeman, J.R.; McNeil, C.F.; et al. Preclinical activity of VX-787, a first-in-class, orally bioavailable inhibitor of the influenza virus polymerase PB2 subunit. Antimicrob. Agents Chemother. 2015, 59, 1569-1582. [CrossRef] [PubMed]

121. Clark, M.P.; Ledeboer, M.W.; Davies, I.; Byrn, R.A.; Jones, S.M.; Perola, E.; Tsai, A.; Jacobs, M.; Nti-Addae, K.; Bandarage, U.K.; et al. Discovery of a novel, first-in-class, orally bioavailable azaindole inhibitor (VX-787) of influenza PB2. J. Med. Chem. 2014, 57, 6668-6678. [CrossRef] [PubMed]

122. Su, C.Y.; Cheng, T.J.; Lin, M.I.; Wang, S.Y.; Huang, W.I.; Lin-Chu, S.Y.; Chen, Y.H.; Wu, C.Y.; Lai, M.M.; Cheng, W.C.; et al. High-throughput identification of compounds targeting influenza RNA-dependent RNA polymerase activity. Proc. Natl. Acad. Sci. USA 2010, 107, 19151-19156. [CrossRef] [PubMed]

123. Amorim, M.J.; Kao, R.Y.; Digard, P. Nucleozin targets cytoplasmic trafficking of viral ribonucleoproteinRAB11 complexes in influenza A virus infection. J. Virol. 2013, 87, 4694-4703. [CrossRef] [PubMed]

124. Pang, B.; Cheung, N.N.; Zhang, W.; Dai, J.; Kao, R.Y.; Zhang, H.; Hao, Q. Structural characterization of H1N1 nucleoprotein-nucleozin binding sites. Sci. Rep. 2016, 6, 29684. [CrossRef] [PubMed]

125. Moss, R.B.; Hansen, C.; Sanders, R.L.; Hawley, S.; Li, T.; Steigbigel, R.T. A phase II study of DAS181, a novel host directed antiviral for the treatment of influenza infection. J. Infect. Dis. 2012, 206, 1844-1851. [CrossRef] [PubMed]

126. Triana-Baltzer, G.B.; Gubareva, L.V.; Klimov, A.I.; Wurtman, D.F.; Moss, R.B.; Hedlund, M.; Larson, J.L.; Belshe, R.B.; Fang, F. Inhibition of neuraminidase inhibitor-resistant influenza virus by DAS181, a novel sialidase fusion protein. PLoS ONE 2009, 4, e7838. [CrossRef] [PubMed]

127. Triana-Baltzer, G.B.; Gubareva, L.V.; Nicholls, J.M.; Pearce, M.B.; Mishin, V.P.; Belser, J.A.; Chen, L.M.; Chan, R.W.; Chan, M.C.; Hedlund, M.; et al. Novel pandemic influenza A(H1N1) viruses are potently inhibited by DAS181, a sialidase fusion protein. PLoS ONE 2009, 4, e7788. [CrossRef] [PubMed]

128. Rallabhandi, P.; Phillips, R.L.; Boukhvalova, M.S.; Pletneva, L.M.; Shirey, K.A.; Gioannini, T.L.; Weiss, J.P.; Chow, J.C.; Hawkins, L.D.; Vogel, S.N.; et al. Respiratory syncytial virus fusion protein-induced toll-like receptor 4 (TLR4) signaling is inhibited by the TLR4 antagonists Rhodobacter sphaeroides lipopolysaccharide and eritoran (E5564) and requires direct interaction with MD-2. mBio 2012, 3, e00218-12. [CrossRef] [PubMed] 
129. Shirey, K.A.; Lai, W.; Scott, A.J.; Lipsky, M.; Mistry, P.; Pletneva, L.M.; Karp, C.L.; McAlees, J.; Gioannini, T.L.; Weiss, J.; et al. The TLR4 antagonist eritoran protects mice from lethal influenza infection. Nature 2013, 497, 498-502. [CrossRef] [PubMed]

130. Darwish, I.; Mubareka, S.; Liles, W.C. Immunomodulatory therapy for severe influenza. Expert Rev. Anti-Infect. Ther. 2011, 9, 807-822. [CrossRef] [PubMed]

131. Gielen, V.; Johnston, S.L.; Edwards, M.R. Azithromycin induces anti-viral responses in bronchial epithelial cells. Eur. Respir. J. 2010, 36, 646-654. [CrossRef] [PubMed]

132. Tavares, L.P.; Teixeira, M.M.; Garcia, C.C. The inflammatory response triggered by influenza virus: A two edged sword. Inflamm. Res. 2017, 66, 283-302. [CrossRef] [PubMed]

133. Hagau, N.; Slavcovici, A.; Gonganau, D.N.; Oltean, S.; Dirzu, D.S.; Brezoszki, E.S.; Maxim, M.; Ciuce, C.; Mlesnite, M.; Gavrus, R.L.; et al. Clinical aspects and cytokine response in severe H1N1 influenza A virus infection. Crit. Care 2010, 14, R203. [CrossRef] [PubMed]

134. To, K.K.; Hung, I.F.; Li, I.W.; Lee, K.L.; Koo, C.K.; Yan, W.W.; Liu, R.; Ho, K.Y.; Chu, K.H.; Watt, C.L.; et al. Delayed clearance of viral load and marked cytokine activation in severe cases of pandemic H1N1 2009 influenza virus infection. Clin. Infect. Dis. 2010, 50, 850-859. [CrossRef] [PubMed]

135. Bermejo-Martin, J.F.; de Lejarazu, R.O.; Pumarola, T.; Rello, J.; Almansa, R.; Ramirez, P.; Martin-Loeches, I.; Varillas, D.; Gallegos, M.C.; Seron, C.; et al. Th1 and Th17 hypercytokinemia as early host response signature in severe pandemic influenza. Crit. Care 2009, 13, R201. [CrossRef] [PubMed]

136. Mauad, T.; Hajjar, L.A.; Callegari, G.D.; da Silva, L.F.; Schout, D.; Galas, F.R.; Alves, V.A.; Malheiros, D.M.; Auler, J.O., Jr.; Ferreira, A.F.; et al. Lung pathology in fatal novel human influenza A (H1N1) infection. Am. J. Respir. Crit. Care Med. 2010, 181, 72-79. [CrossRef] [PubMed]

137. Stein, R.T.; Sherrill, D.; Morgan, W.J.; Holberg, C.J.; Halonen, M.; Taussig, L.M.; Wright, A.L.; Martinez, F.D. Respiratory syncytial virus in early life and risk of wheeze and allergy by age 13 years. Lancet 1999, 354, 541-545. [CrossRef]

138. Wright, A.L.; Holberg, C.J.; Taussig, L.M.; Martinez, F.D. Relationship of infant feeding to recurrent wheezing at age 6 years. Arch. Pediatr. Adolesc. Med. 1995, 149, 758-763. [CrossRef] [PubMed]

139. Lay, M.K.; Gonzalez, P.A.; Leon, M.A.; Cespedes, P.F.; Bueno, S.M.; Riedel, C.A.; Kalergis, A.M. Advances in understanding respiratory syncytial virus infection in airway epithelial cells and consequential effects on the immune response. Microbes Infect. 2013, 15, 230-242. [CrossRef] [PubMed]

140. Durbin, J.E.; Durbin, R.K. Respiratory syncytial virus-induced immunoprotection and immunopathology. Viral Immunol. 2004, 17, 370-380. [CrossRef] [PubMed]

141. Tripp, R.A. Pathogenesis of respiratory syncytial virus infection. Viral Immunol. 2004, 17, 165-181. [CrossRef] [PubMed]

142. Sigurs, N.; Aljassim, F.; Kjellman, B.; Robinson, P.D.; Sigurbergsson, F.; Bjarnason, R.; Gustafsson, P.M. Asthma and allergy patterns over 18 years after severe RSV bronchiolitis in the first year of life. Thorax 2010, 65, 1045-1052. [CrossRef] [PubMed]

143. Newton, A.H.; Cardani, A.; Braciale, T.J. The host immune response in respiratory virus infection: Balancing virus clearance and immunopathology. Semin. Immunopathol. 2016, 38, 471-482. [CrossRef] [PubMed]

144. Openshaw, P.J.; Tregoning, J.S. Immune responses and disease enhancement during respiratory syncytial virus infection. Clin. Microbiol. Rev. 2005, 18, 541-555. [CrossRef] [PubMed]

145. Ramos, I.; Fernandez-Sesma, A. Modulating the innate immune response to influenza A virus: Potential therapeutic use of anti-inflammatory drugs. Front. Immunol. 2015, 6, 361. [CrossRef] [PubMed]

146. Mukherjee, S.; Lukacs, N.W. Innate immune responses to respiratory syncytial virus infection. Curr. Top. Microbiol. Immunol. 2013, 372, 139-154. [PubMed]

147. Baum, A.; Garcia-Sastre, A. Induction of type I interferon by RNA viruses: Cellular receptors and their substrates. Amino Acids 2010, 38, 1283-1299. [CrossRef] [PubMed]

148. Kawai, T.; Akira, S. Signaling to NF-кB by toll-like receptors. Trends Mol. Med. 2007, 13, 460-469. [CrossRef] [PubMed]

149. Kawai, T.; Akira, S. Antiviral signaling through pattern recognition receptors. J. Biochem. 2007, 141, 137-145. [CrossRef] [PubMed]

150. Koyama, S.; Ishii, K.J.; Kumar, H.; Tanimoto, T.; Coban, C.; Uematsu, S.; Kawai, T.; Akira, S. Differential role of TLR- and RLR-signaling in the immune responses to influenza A virus infection and vaccination. J. Immunol. 2007, 179, 4711-4720. [CrossRef] [PubMed] 
151. Kulkarni, R.; Behboudi, S.; Sharif, S. Insights into the role of toll-like receptors in modulation of T cell responses. Cell Tissue Res. 2011, 343, 141-152. [CrossRef] [PubMed]

152. Sha, Q.; Truong-Tran, A.Q.; Plitt, J.R.; Beck, L.A.; Schleimer, R.P. Activation of airway epithelial cells by toll-like receptor agonists. Am. J. Respir. Cell Mol. 2004, 31, 358-364. [CrossRef] [PubMed]

153. Lee, S.M.; Kok, K.H.; Jaume, M.; Cheung, T.K.; Yip, T.F.; Lai, J.C.; Guan, Y.; Webster, R.G.; Jin, D.Y.; Peiris, J.S. Toll-like receptor 10 is involved in induction of innate immune responses to influenza virus infection. Proc. Natl. Acad. Sci. USA 2014, 111, 3793-3798. [CrossRef] [PubMed]

154. Monick, M.M.; Yarovinsky, T.O.; Powers, L.S.; Butler, N.S.; Carter, A.B.; Gudmundsson, G.; Hunninghake, G.W. Respiratory syncytial virus up-regulates TLR4 and sensitizes airway epithelial cells to endotoxin. J. Biol. Chem. 2003, 278, 53035-53044. [CrossRef] [PubMed]

155. Xie, X.H.; Law, H.K.; Wang, L.J.; Li, X.; Yang, X.Q.; Liu, E.M. Lipopolysaccharide induces IL-6 production in respiratory syncytial virus-infected airway epithelial cells through the toll-like receptor 4 signaling pathway. Pediatr. Res. 2009, 65, 156-162. [CrossRef] [PubMed]

156. Takeuchi, O.; Akira, S. Pattern recognition receptors and inflammation. Cell 2010, 140, 805-820. [CrossRef] [PubMed]

157. Gack, M.U. Mechanisms of RIG-I-Like receptor activation and manipulation by viral pathogens. J. Virol. 2014, 88, 5213-5216. [CrossRef] [PubMed]

158. Rehwinkel, J.; Tan, C.P.; Goubau, D.; Schulz, O.; Pichlmair, A.; Bier, K.; Robb, N.; Vreede, F.; Barclay, W.; Fodor, E.; et al. RIG-I detects viral genomic RNA during negative-strand RNA virus infection. Cell 2010, 140, 397-408. [CrossRef] [PubMed]

159. Kowalinski, E.; Lunardi, T.; McCarthy, A.A.; Louber, J.; Brunel, J.; Grigorov, B.; Gerlier, D.; Cusack, S. Structural basis for the activation of innate immune pattern-recognition receptor RIG-Ii by viral RNA. Cell 2011, 147, 423-435. [CrossRef] [PubMed]

160. Owen, D.M.; Gale, M., Jr. Fighting the flu with inflammasome signaling. Immunity 2009, 30, 476-478. [CrossRef] [PubMed]

161. Pothlichet, J.; Meunier, I.; Davis, B.K.; Ting, J.P.; Skamene, E.; von Messling, V.; Vidal, S.M. Type I IFN triggers RIG-I/TLR3/NLRP3-dependent inflammasome activation in influenza A virus infected cells. PLoS Pathog. 2013, 9, e1003256. [CrossRef] [PubMed]

162. Iwasaki, A.; Pillai, P.S. Innate immunity to influenza virus infection. Nat. Rev. Immunol. 2014, 14, $315-328$. [CrossRef] [PubMed]

163. Martinon, F.; Mayor, A.; Tschopp, J. The inflammasomes: Guardians of the body. Annu. Rev. Immunol. 2009, 27, 229-265. [CrossRef] [PubMed]

164. Allen, I.C.; Scull, M.A.; Moore, C.B.; Holl, E.K.; McElvania-TeKippe, E.; Taxman, D.J.; Guthrie, E.H.; Pickles, R.J.; Ting, J.P. The NLRP3 inflammasome mediates in vivo innate immunity to influenza A virus through recognition of viral RNA. Immunity 2009, 30, 556-565. [CrossRef] [PubMed]

165. Triantafilou, K.; Kar, S.; Vakakis, E.; Kotecha, S.; Triantafilou, M. Human respiratory syncytial virus viroporin $\mathrm{SH}$ : A viral recognition pathway used by the host to signal inflammasome activation. Thorax 2013, 68, 66-75. [CrossRef] [PubMed]

166. McAuley, J.L.; Tate, M.D.; MacKenzie-Kludas, C.J.; Pinar, A.; Zeng, W.; Stutz, A.; Latz, E.; Brown, L.E.; Mansell, A. Activation of the NLRP3 inflammasome by IAV virulence protein PB1-F2 contributes to severe pathophysiology and disease. PLoS Pathog. 2013, 9, e1003392. [CrossRef] [PubMed]

167. Sabbah, A.; Chang, T.H.; Harnack, R.; Frohlich, V.; Tominaga, K.; Dube, P.H.; Xiang, Y.; Bose, S. Activation of innate immune antiviral responses by NOD2. Nat. Immunol. 2009, 10, 1073-1080. [CrossRef] [PubMed]

168. Lupfer, C.; Thomas, P.G.; Kanneganti, T.D. Nucleotide oligomerization and binding domain 2-dependent dendritic cell activation is necessary for innate immunity and optimal CD8 ${ }^{+} \mathrm{T}$ cell responses to influenza A virus infection. J. Virol. 2014, 88, 8946-8955. [CrossRef] [PubMed]

169. Tisoncik, J.R.; Korth, M.J.; Simmons, C.P.; Farrar, J.; Martin, T.R.; Katze, M.G. Into the eye of the cytokine storm. Microbiol. Mol. Biol. Rev. 2012, 76, 16-32. [CrossRef] [PubMed]

170. Zhang, J.M.; An, J. Cytokines, inflammation, and pain. Int. Anesthesiol. Clin. 2007, 45, 27-37. [CrossRef] [PubMed]

171. Le Goffic, R.; Pothlichet, J.; Vitour, D.; Fujita, T.; Meurs, E.; Chignard, M.; Si-Tahar, M. Cutting edge: Influenza A virus activates TLR3-dependent inflammatory and RIG-I-dependent antiviral responses in human lung epithelial cells. J. Immunol. 2007, 178, 3368-3372. [CrossRef] [PubMed] 
172. Le Goffic, R.; Balloy, V.; Lagranderie, M.; Alexopoulou, L.; Escriou, N.; Flavell, R.; Chignard, M.; Si-Tahar, M. Detrimental contribution of the toll-like receptor (TLR)3 to influenza A virus-induced acute pneumonia. PLoS Pathog. 2006, 2, e53. [CrossRef] [PubMed]

173. Groskreutz, D.J.; Monick, M.M.; Powers, L.S.; Yarovinsky, T.O.; Look, D.C.; Hunninghake, G.W. Respiratory syncytial virus induces TLR3 protein and protein kinase $\mathrm{R}$, leading to increased double-stranded RNA responsiveness in airway epithelial cells. J. Immunol. 2006, 176, 1733-1740. [CrossRef] [PubMed]

174. Rudd, B.D.; Burstein, E.; Duckett, C.S.; Li, X.; Lukacs, N.W. Differential role for TLR3 in respiratory syncytial virus-induced chemokine expression. J. Virol. 2005, 79, 3350-3357. [CrossRef] [PubMed]

175. Tripp, R.A.; Oshansky, C.; Alvarez, R. Cytokines and respiratory syncytial virus infection. Proc. Am. Thorac. Soc. 2005, 2, 147-149. [CrossRef] [PubMed]

176. To, K.F.; Chan, P.K.; Chan, K.F.; Lee, W.K.; Lam, W.Y.; Wong, K.F.; Tang, N.L.; Tsang, D.N.; Sung, R.Y.; Buckley, T.A.; et al. Pathology of fatal human infection associated with avian influenza a H5N1 virus. J. Med. Virol. 2001, 63, 242-246. [CrossRef]

177. Bonville, C.A.; Rosenberg, H.F.; Domachowske, J.B. Macrophage inflammatory protein-1 $\alpha$ and RANTES are present in nasal secretions during ongoing upper respiratory tract infection. Pediatr. Allergy Immunol. 1999, 10, 39-44. [CrossRef] [PubMed]

178. Mohapatra, S.S.; Boyapalle, S. Epidemiologic, experimental, and clinical links between respiratory syncytial virus infection and asthma. Clin. Microbiol. Rev. 2008, 21, 495-504. [CrossRef] [PubMed]

179. Kuiken, T.; Taubenberger, J.K. Pathology of human influenza revisited. Vaccine 2008, 26, D59-D66. [CrossRef] [PubMed]

180. Chiaretti, A.; Pulitano, S.; Barone, G.; Ferrara, P.; Romano, V.; Capozzi, D.; Riccardi, R. IL-1 $\beta$ and IL-6 upregulation in children with H1N1 influenza virus infection. Mediat. Inflamm. 2013, 2013, 495848. [CrossRef] [PubMed]

181. Yu, X.; Zhang, X.; Zhao, B.; Wang, J.; Zhu, Z.; Teng, Z.; Shao, J.; Shen, J.; Gao, Y.; Yuan, Z.; et al. Intensive cytokine induction in pandemic H1N1 influenza virus infection accompanied by robust production of IL-10 and IL-6. PLoS ONE 2011, 6, e28680. [CrossRef] [PubMed]

182. Knipe, D.M.; Howley, P.M. Fields Virology, 6th ed.; Wolters Kluwer/Lippincott Williams and Wilkins Health: Philadelphia, PA, USA, 2013; Volume 59, p. 2.

183. Kochs, G.; Garcia-Sastre, A.; Martinez-Sobrido, L. Multiple anti-interferon actions of the influenza A virus NS1 protein. J. Virol. 2007, 81, 7011-7021. [CrossRef] [PubMed]

184. Ludwig, S.; Wang, X.; Ehrhardt, C.; Zheng, H.; Donelan, N.; Planz, O.; Pleschka, S.; Garcia-Sastre, A.; Heins, G.; Wolff, T. The influenza a virus NS1 protein inhibits activation of Jun N-terminal kinase and AP-1 transcription factors. J. Virol. 2002, 76, 11166-11171. [CrossRef] [PubMed]

185. Mibayashi, M.; Martinez-Sobrido, L.; Loo, Y.M.; Cardenas, W.B.; Gale, M., Jr.; Garcia-Sastre, A. Inhibition of retinoic acid-inducible gene I-mediated induction of $\beta$ interferon by the NS1 protein of influenza A virus. J. Virol. 2007, 81, 514-524. [CrossRef] [PubMed]

186. Noah, D.L.; Twu, K.Y.; Krug, R.M. Cellular antiviral responses against influenza A virus are countered at the posttranscriptional level by the viral NS1A protein via its binding to a cellular protein required for the $3^{\prime}$ end processing of cellular pre-mRNAs. Virology 2003, 307, 386-395. [CrossRef]

187. Spann, K.A.; Tran, K.C.; Chi, B.; Rabin, R.L.; Collins, P.L. Suppression of the induction of $\alpha, \beta$, and $\lambda$ interferons by the NS1 and NS2 proteins of human respiratory syncytial virus in human epithelial cells and macrophages. J. Virol. 2004, 78, 6705. [CrossRef]

188. Swedan, S.; Musiyenko, A.; Barik, S. Respiratory syncytial virus nonstructural proteins decrease levels of multiple members of the cellular interferon pathways. J. Virol. 2009, 83, 9682-9693. [CrossRef] [PubMed]

189. Zheng, J.; Yang, P.; Tang, Y.; Pan, Z.; Zhao, D. Respiratory syncytial virus nonstructural proteins upregulate SOCS1 and SOCS3 in the different manner from endogenous IFN signaling. J. Immunol. Res. 2015, 2015, 738547. [CrossRef] [PubMed]

190. Oshansky, C.M.; Krunkosky, T.M.; Barber, J.; Jones, L.P.; Tripp, R.A. Respiratory syncytial virus proteins modulate suppressors of cytokine signaling 1 and 3 and the type I interferon response to infection by a toll-like receptor pathway. Viral Immunol. 2009, 22, 147-161. [CrossRef] [PubMed]

191. Tripp, R.A.; Jones, L.P.; Haynes, L.M.; Zheng, H.; Murphy, P.M.; Anderson, L.J. CX3C chemokine mimicry by respiratory syncytial virus G glycoprotein. Nat. Immunol. 2001, 2, 732-738. [CrossRef] [PubMed] 
192. Bukreyev, A.; Yang, L.; Collins, P.L. The secreted G protein of human respiratory syncytial virus antagonizes antibody-mediated restriction of replication involving macrophages and complement. J. Virol. 2012, 86, 10880-10884. [CrossRef] [PubMed]

193. Bukreyev, A.; Yang, L.; Fricke, J.; Cheng, L.; Ward, J.M.; Murphy, B.R.; Collins, P.L. The secreted form of respiratory syncytial virus $\mathrm{G}$ glycoprotein helps the virus evade antibody-mediated restriction of replication by acting as an antigen decoy and through effects on fc receptor-bearing leukocytes. J. Virol. 2008, 82, 12191-12204. [CrossRef] [PubMed]

194. Zhang, W.; Choi, Y.; Haynes, L.M.; Harcourt, J.L.; Anderson, L.J.; Jones, L.P.; Tripp, R.A. Vaccination to induce antibodies blocking the CX3C-CX3CR1 interaction of respiratory syncytial virus $G$ protein reduces pulmonary inflammation and virus replication in mice. J. Virol. 2010, 84, 1148-1157. [CrossRef] [PubMed]

195. Polack, F.P.; Irusta, P.M.; Hoffman, S.J.; Schiatti, M.P.; Melendi, G.A.; Delgado, M.F.; Laham, F.R.; Thumar, B.; Hendry, R.M.; Melero, J.A.; et al. The cysteine-rich region of respiratory syncytial virus attachment protein inhibits innate immunity elicited by the virus and endotoxin. Proc. Natl. Acad. Sci. USA 2005, 102, 8996-9001. [CrossRef] [PubMed]

196. Mathew, C.; Ghildyal, R. CRM1 inhibitors for antiviral therapy. Front. Microbiol. 2017, 8, 1171. [CrossRef] [PubMed]

197. Zhang, X.; Yamada, M.; Mabuchi, N.; Shida, H. Cellular requirements for CRM1 import and export. J. Biochem. 2003, 134, 759-764. [CrossRef] [PubMed]

198. Dickmanns, A.; Monecke, T.; Ficner, R. Structural basis of targeting the exportin CRM1 in cancer. Cells 2015, 4, 538-568. [CrossRef] [PubMed]

199. Turner, J.G.; Dawson, J.; Cubitt, C.L.; Baz, R.; Sullivan, D.M. Inhibition of CRM1-dependent nuclear export sensitizes malignant cells to cytotoxic and targeted agents. Semin. Cancer Biol. 2014, 27, 62-73. [CrossRef] [PubMed]

200. Gorlich, D.; Kutay, U. Transport between the cell nucleus and the cytoplasm. Annu. Rev. Cell Dev. Biol. 1999, 15, 607-660. [CrossRef] [PubMed]

201. Lim, R.Y.; Aebi, U.; Fahrenkrog, B. Towards reconciling structure and function in the nuclear pore complex. Histochem. Cell Biol. 2008, 129, 105-116. [CrossRef] [PubMed]

202. Reichelt, R.; Holzenburg, A.; Buhle, E.L., Jr.; Jarnik, M.; Engel, A.; Aebi, U. Correlation between structure and mass distribution of the nuclear pore complex and of distinct pore complex components. J. Cell Biol. 1990, 110, 883-894. [CrossRef] [PubMed]

203. Mattaj, I.W.; Englmeier, L. Nucleocytoplasmic transport: The soluble phase. Annu. Rev. Biochem. 1998, 67, 265-306. [CrossRef] [PubMed]

204. Fung, H.Y.; Chook, Y.M. Atomic basis of CRM1-cargo recognition, release and inhibition. Semin. Cancer Biol. 2014, 27, 52-61. [CrossRef] [PubMed]

205. Xu, D.; Grishin, N.V.; Chook, Y.M. NESdb: A database of NES-containing CRM1 cargoes. Mol. Biol. Cell 2012, 23, 3673-3676. [CrossRef] [PubMed]

206. Fornerod, M.; Ohno, M.; Yoshida, M.; Mattaj, I.W. CRM1 is an export receptor for leucine-rich nuclear export signals. Cell 1997, 90, 1051-1060. [CrossRef]

207. Fukuda, M.; Asano, S.; Nakamura, T.; Adachi, M.; Yoshida, M.; Yanagida, M.; Nishida, E. CRM1 is responsible for intracellular transport mediated by the nuclear export signal. Nature 1997, 390, 308-311. [PubMed]

208. Dong, X.; Biswas, A.; Chook, Y.M. Structural basis for assembly and disassembly of the CRM1 nuclear export complex. Nat. Struct. Mol. Biol. 2009, 16, 558-560. [CrossRef] [PubMed]

209. Dong, X.; Biswas, A.; Suel, K.E.; Jackson, L.K.; Martinez, R.; Gu, H.; Chook, Y.M. Structural basis for leucine-rich nuclear export signal recognition by CRM1. Nature 2009, 458, 1136-1141. [CrossRef] [PubMed]

210. Monecke, T.; Guttler, T.; Neumann, P.; Dickmanns, A.; Gorlich, D.; Ficner, R. Crystal structure of the nuclear export receptor CRM1 in complex with Snurportin1 and RanGTP. Science 2009, 324, 1087-1091. [CrossRef] [PubMed]

211. Breit, M.N.; Kisseberth, W.C.; Bear, M.D.; Landesman, Y.; Kashyap, T.; McCauley, D.; Kauffman, M.G.; Shacham, S.; London, C.A. Biologic activity of the novel orally bioavailable selective inhibitor of nuclear export (SINE) KPT-335 against canine melanoma cell lines. BMC Vet. Res. 2014, 10, 160. [CrossRef] [PubMed]

212. Gerecitano, J. SINE (selective inhibitor of nuclear export)-Translational science in a new class of anti-cancer agents. J. Hematol. Oncol. 2014, 7, 67. [CrossRef] [PubMed] 
213. Grayton, J.E.; Miller, T.; Wilson-Robles, H. In vitro evaluation of selective inhibitors of nuclear export (SINE) drugs KPT-185 and KPT-335 against canine mammary carcinoma and transitional cell carcinoma tumor initiating cells. Vet. Comp. Oncol. 2017, 15, 1455-1467. [CrossRef] [PubMed]

214. Muqbil, I.; Aboukameel, A.; Elloul, S.; Carlson, R.; Senapedis, W.; Baloglu, E.; Kauffman, M.; Shacham, S.; Bhutani, D.; Zonder, J.; et al. Anti-tumor activity of selective inhibitor of nuclear export (SINE) compounds, is enhanced in non-Hodgkin lymphoma through combination with mTOR inhibitor and dexamethasone. Cancer Lett. 2016, 383, 309-317. [CrossRef] [PubMed]

215. Newlands, E.S.; Rustin, G.J.; Brampton, M.H. Phase I trial of elactocin. Br. J. Cancer 1996, 74, 648-649. [CrossRef] [PubMed]

216. Kudo, N.; Wolff, B.; Sekimoto, T.; Schreiner, E.P.; Yoneda, Y.; Yanagida, M.; Horinouchi, S.; Yoshida, M. Leptomycin B inhibition of signal-mediated nuclear export by direct binding to CRM1. Exp. Cell Res. 1998, 242, 540-547. [CrossRef] [PubMed]

217. Etchin, J.; Sun, Q.; Kentsis, A.; Farmer, A.; Zhang, Z.C.; Sanda, T.; Mansour, M.R.; Barcelo, C.; McCauley, D.; Kauffman, M.; et al. Antileukemic activity of nuclear export inhibitors that spare normal hematopoietic cells. Leukemia 2013, 27, 66-74. [CrossRef] [PubMed]

218. Perwitasari, O.; Johnson, S.; Yan, X.; Register, E.; Crabtree, J.; Gabbard, J.; Howerth, E.; Shacham, S.; Carlson, R.; Tamir, S.; et al. Antiviral efficacy of verdinexor in vivo in two animal models of influenza A virus infection. PLoS ONE 2016, 11, e0167221. [CrossRef] [PubMed]

219. London, C.A.; Bernabe, L.F.; Barnard, S.; Kisseberth, W.C.; Borgatti, A.; Henson, M.; Wilson, H.; Jensen, K.; Ito, D.; Modiano, J.F.; et al. Preclinical evaluation of the novel, orally bioavailable selective inhibitor of nuclear export (SINE) KPT-335 in spontaneous canine cancer: Results of a phase I study. PLoS ONE 2014, 9, e87585. [CrossRef] [PubMed]

220. Huang, T.T.; Kudo, N.; Yoshida, M.; Miyamoto, S. A nuclear export signal in the N-terminal regulatory domain of $\mathrm{IkB} \alpha$ controls cytoplasmic localization of inactive NF-kB/IkB $\alpha$ complexes. Proc. Natl. Acad. Sci. USA 2000, 97, 1014-1019. [CrossRef] [PubMed]

221. Tam, W.F.; Lee, L.H.; Davis, L.; Sen, R. Cytoplasmic sequestration of Rel proteins by IkB $\alpha$ requires CRM1-dependent nuclear export. Mol. Cell. Biol. 2000, 20, 2269-2284. [CrossRef] [PubMed]

222. Arenzana-Seisdedos, F.; Thompson, J.; Rodriguez, M.S.; Bachelerie, F.; Thomas, D.; Hay, R.T. Inducible nuclear expression of newly synthesized IkB $\alpha$ negatively regulates DNA-binding and transcriptional activities of NF-кB. Mol. Cell. Biol. 1995, 15, 2689-2696. [CrossRef] [PubMed]

223. Arenzana-Seisdedos, F.; Turpin, P.; Rodriguez, M.; Thomas, D.; Hay, R.T.; Virelizier, J.L.; Dargemont, C. Nuclear localization of $\mathrm{i} \kappa \mathrm{B} \alpha$ promotes active transport of NF-KB from the nucleus to the cytoplasm. J. Cell Sci. 1997, 110 Pt 3, 369-378. [PubMed]

224. Renard, P.; Percherancier, Y.; Kroll, M.; Thomas, D.; Virelizier, J.L.; Arenzana-Seisdedos, F.; Bachelerie, F.

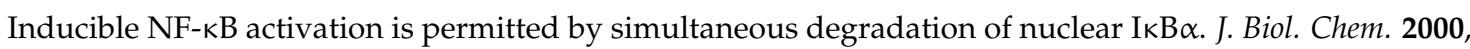
275, 15193-15199. [CrossRef] [PubMed]

(C) 2018 by the authors. Licensee MDPI, Basel, Switzerland. This article is an open access article distributed under the terms and conditions of the Creative Commons Attribution (CC BY) license (http://creativecommons.org/licenses/by/4.0/). 